San Jose State University

SJSU ScholarWorks

Master's Theses

Master's Theses and Graduate Research

Fall 2013

\title{
The genetic diversity and population structure of the dugongs (Dugong dugon) of Thailand
}

Jessie Barr Bushell

San Jose State University

Follow this and additional works at: https://scholarworks.sjsu.edu/etd_theses

\section{Recommended Citation}

Bushell, Jessie Barr, "The genetic diversity and population structure of the dugongs (Dugong dugon) of Thailand" (2013). Master's Theses. 4379.

DOI: https://doi.org/10.31979/etd.9mna-xz4c

https://scholarworks.sjsu.edu/etd_theses/4379

This Thesis is brought to you for free and open access by the Master's Theses and Graduate Research at SJSU ScholarWorks. It has been accepted for inclusion in Master's Theses by an authorized administrator of SJSU ScholarWorks. For more information, please contact scholarworks@sjsu.edu. 
THE GENETIC DIVERSITY AND POPULATION STRUCTURE OF THE DUGONGS (DUGONG DUGON) OF THAILAND

\author{
A Thesis \\ Presented to \\ The Faculty of the Department of Biological Sciences \\ San José State University \\ In Partial Fulfillment \\ of the Requirements for the Degree \\ Master of Science
}

by

Jessie B. Bushell

December 2013 
(C) 2013

Jessie B. Bushell

ALL RIGHTS RESERVED 
The Designated Thesis Committee Approves the Thesis Titled

THE GENETIC DIVERSITY AND POPULATION STRUCTURE OF THE DUGONGS (DUGONG DUGON) OF THAILAND

by Jessie B. Bushell

APPROVED FOR THE DEPARTMENT OF BIOLOGICAL SCEINCES

SAN JOSÉ STATE UNIVERSITY

December 2013

Dr. Leslee A. Parr, Department of Biological Sciences

Dr. Joshua Mackie, Department of Biological Sciences

Dr. Ellen Hines, Romberg Tiburon Center for Environmental Studies,

San Francisco State University 


\section{ABSTRACT \\ THE GENETIC DIVERSITY AND POPULATION STRUCTURE OF THE DUGONGS (DUGONG DUGON) OF THAILAND}

by Jessie B. Bushell

The dugong (Dugong dugon) is indigenous to the coastal waters of the Indo-Pacific Ocean and is vulnerable to extinction throughout its range due primarily to anthropogenic effects. In Thailand the population of dugongs is approximately 250 animals and is found in fragmented habitats along the Thai coast. Genetic studies were implemented in this study to assess regional genetic composition and determine if there is variation in the D-loop sequences or microsatellites consistent with philopatry to regions, by males or females, or indicating dispersal. Utilizing D-loop sequences, 27 haplotypes were found that grouped into three haplogroups that were not differentiated by region but did show spatial differentiation when analyzed with $F$-statistics. Microsatellite analysis provided evidence of three populations - one in the Gulf of Thailand and two in the Andaman Sea (north Andaman Sea and Trang Province). Weak structuring of mtDNA variation occurs between neighboring Andaman Sea regions and may indicate philopatry by females due to high quality seagrass meadows in Trang Province especially. Nuclear DNA analysis provided a signal of dispersal between the two sides of the peninsula explaining how genetic variation has remained at levels above expected for a species with declining numbers. Utilizing established bottleneck tests, no evidence was found indicating a bottleneck in the population, though there was a signal of population decline, especially in the Gulf region. Overall recommendations are for further molecular studies utilizing a 
greater sample size and additional populations in the Indo-Pacific region to determine historic dispersal and a more comprehensive study of population viability. 


\section{ACKNOWLEDGEMENTS}

I want to thank Kanjana Adulyanukosol and the Phuket Marine Biological Center for their ongoing support of this research project and for generously sharing dugong samples and knowledge. This project would not have happened without the Kanjana's commitment to conserving the dugongs of Thailand and she is an inspiration to many, including myself. To Dr. Leslee Parr, Dr. Josh Mackie and Dr. Ellen Hines, my sincerest thanks go to you three for mentoring me through this long process and for all the editing, data crunching, and ongoing support. A special indebtedness goes to Josh Mackie for all the many days and nights working with me to bring this project to fruition. An enormous thank you goes to Dr. Frank Cipriano of the San Francisco State University Conservation Genetics Lab for taking so much time to answer questions, check my microsatellite alleles, and just encouraging me when I wanted to give up. My appreciation goes to Dr.

Seifu Seyoum, Michelle Davis and Mike Tringali of FWC, Susan Carney of Mote Marine Lab, and Bob Bonde and Maggie Hunter of the University of Florida for sharing information, materials and samples essential to this project. To my dearest friend Dr. Kate McFadden, I am indebted to you for setting timelines that I always missed and for the calls that kept me somewhat sane. And finally, but not last, to my family, thank you for never stopping to encourage me to finish even when it meant late nights at the lab, forgotten dinner dates, and missed family days together.

An Arthur and Karin Nelson Research Fellowship and an SJSU Alumni Association Dean's Scholarship supported this project. 


\section{TABLE OF CONTENTS}

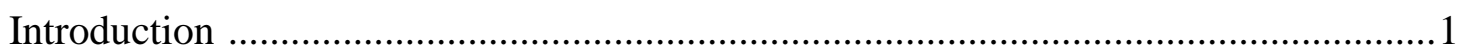

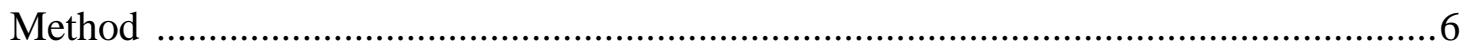

Study Site/Sample Collection ......................................................................6

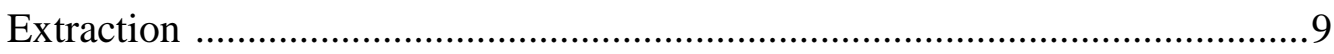

Control Region Design and Amplification ...................................................

Microsatellite Amplification .......................................................................11

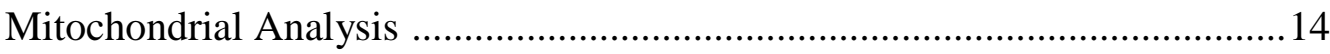

Microsatellite Analysis ..............................................................................15

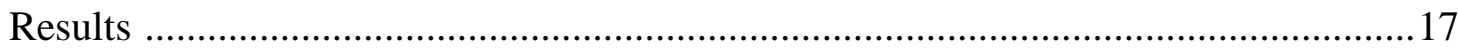

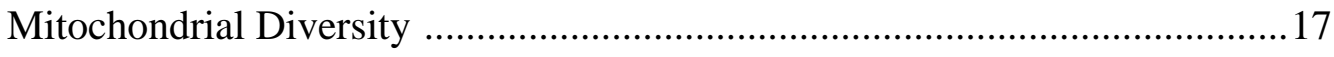

Microsatellite Diversity ........................................................................22

Population Structure Analysis ....................................................................24

Diversity Level Comparisons and Tests of Historic Effects .............................29

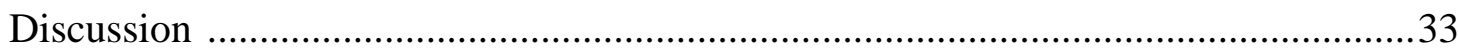

Regional Population Structure ………………………..................................40

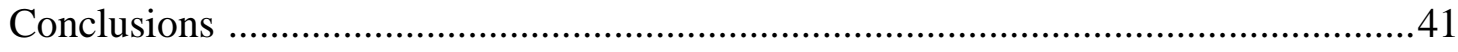

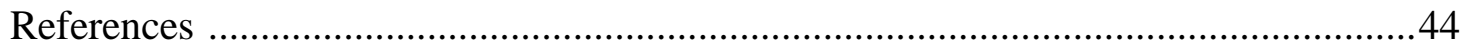




\section{LIST OF FIGURES}

Figure 1. Geographic map of Thailand ….......................................................4

Figure 2. Bayesian tree of control region sequences of 31 dugong ..........................19

Figure 3. Parsimony network of 19 control region (left domain) haplotypes

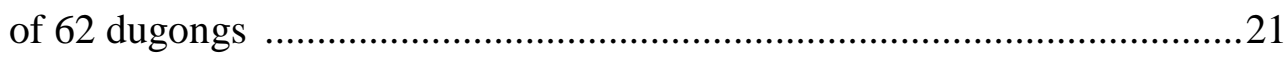

Figure 4. STRUCTURE diagram summarizing microsatellite genotype similarity and area of sampling ........................................................26

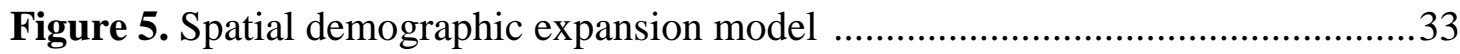

Figure 6. Observed heterozygosity for nuclear DNA microsatellite markers developed for both manatee and dugongs 37 


\section{LIST OF TABLES}

Table 1. Records of stranded dugongs used in genetic analyses .............................

Table 2. Locus information and characteristics for the 10 microsatellite loci

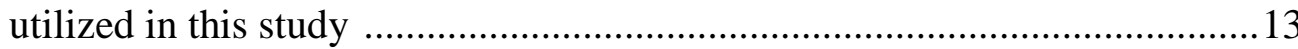

Table 3. Probabilities reflecting fit of allele frequencies and Hardy-Weinberg proportion for microsatellite loci …..................................................23

Table 4. Pairwise comparisons of genetic differentiation among the Gulf of Thailand, the northern Andaman Sea region and Trang .28

Table 5. Estimates of genetic diversity of the 5' end of the control region (445 base pairs) in Thailand dugong samples 


\section{Introduction}

The dugong (Dugong dugon) is a member of the order Sirenia and is the only strictly herbivorous marine mammal. Indigenous to the coastal waters of the Indo-Pacific Ocean, the dugong is listed as vulnerable to extinction by the International Union for Conservation of Nature and Natural Resources (Marsh, 2008) and in the Convention on International Trade in Endangered Species of Wilde Fauna and Flora (CITES Appendix I [19/07/00]), and on Appendix II of the Convention on Migratory Species (the CMS) due to declines in population and degradation of habitat (CITES Appendix I [19/07/00]).

Though there is limited information about dugong population and distribution available for most of Asia, for the past half century a high birth rate and significant human population migration to coastal areas has been well documented (Hines et al., 2012). Increased population growth has led to coastal development and a reduction in sustainability of seaside resources throughout Asia (Hines et al., 2012). Since dugongs are restricted to coastal habitats where they rely upon seagrass beds or meadows for feeding (Anderson, 1979; Heinsohn et al., 1977; Tikel, 1997), they are heavily impacted by human activities (Marsh et al., 2002) and are in direct competition with humans for resources in many of these areas. The most important threats to dugongs over much of the Indo-Pacific are incidental capture in fishing nets or death due to destructive fishing practices, effects of coastal habitat alteration, and hunting for meat or medicinal purposes (Hines et al., 2012). Further complicating dugong conservation is an insufficient understanding of its distribution and abundance.

Thailand has a 2,300 km coastline that is rich in biodiversity. The dugong has 
been under the protection of the Thai Fisheries Act since 1947 (Adulyanukosol, 1999). Once common along both the Andaman Sea and Gulf of Thailand coasts (Nateekanganalarp \& Sudara, 1994), the dugong has declined severely. Aerial surveys in 1997, 1999, 2000, and 2001 found only small population groups existed in the Andaman Sea from Ranong to Satun Provinces, with the largest viable population in Trang (Adulyanukosol, 1999; Hines, 2005). Hines (2005) confirmed that Trang Province had the largest remaining population and estimated the total to be 120 individuals. Adulyanukosol and Thongsukdee (2005) surveyed Trang province after the December 2004 tsunami and sighted 126 dugongs in one day of aerial surveys providing evidence that the dugongs had survived the tsunami without significant impact on the population. The survey also confirmed that a healthy dugong population still exists in Trang province and is most likely the largest and healthiest group of dugongs in Southeast and Eastern Asia (Hines, 2002; Hines et al., 2005). Some 200 dugongs were estimated a decade ago in the Andaman Sea region as a whole (Hines, 2002). Smaller numbers still persisted in eastern Thailand near the border with Cambodia and throughout the Gulf of Thailand (Hines et al., 2003, 2004) with a total population estimate of 50 individuals in the gulf (Andulyanukosol, 2007; Andulyanukosol \& Thongsukdee, 2005, 2006). Accordingly, the support and further development of conservation strategies is critical to dugong stocks in Thailand.

The current study reports an assessment of the regional genetic composition of Thailand area dugongs using mitochondrial D-loop sequences and microsatellite loci on tissue from dead dugongs found stranded or floating. The tissue samples were dried or 
stored in ethanol and deposited at the Phuket Marine Biological Center between 1982 and 2008 from locations on the Gulf of Thailand on the east side of the Thailand Peninsula and the Andaman Sea on the western side (Figure 1).

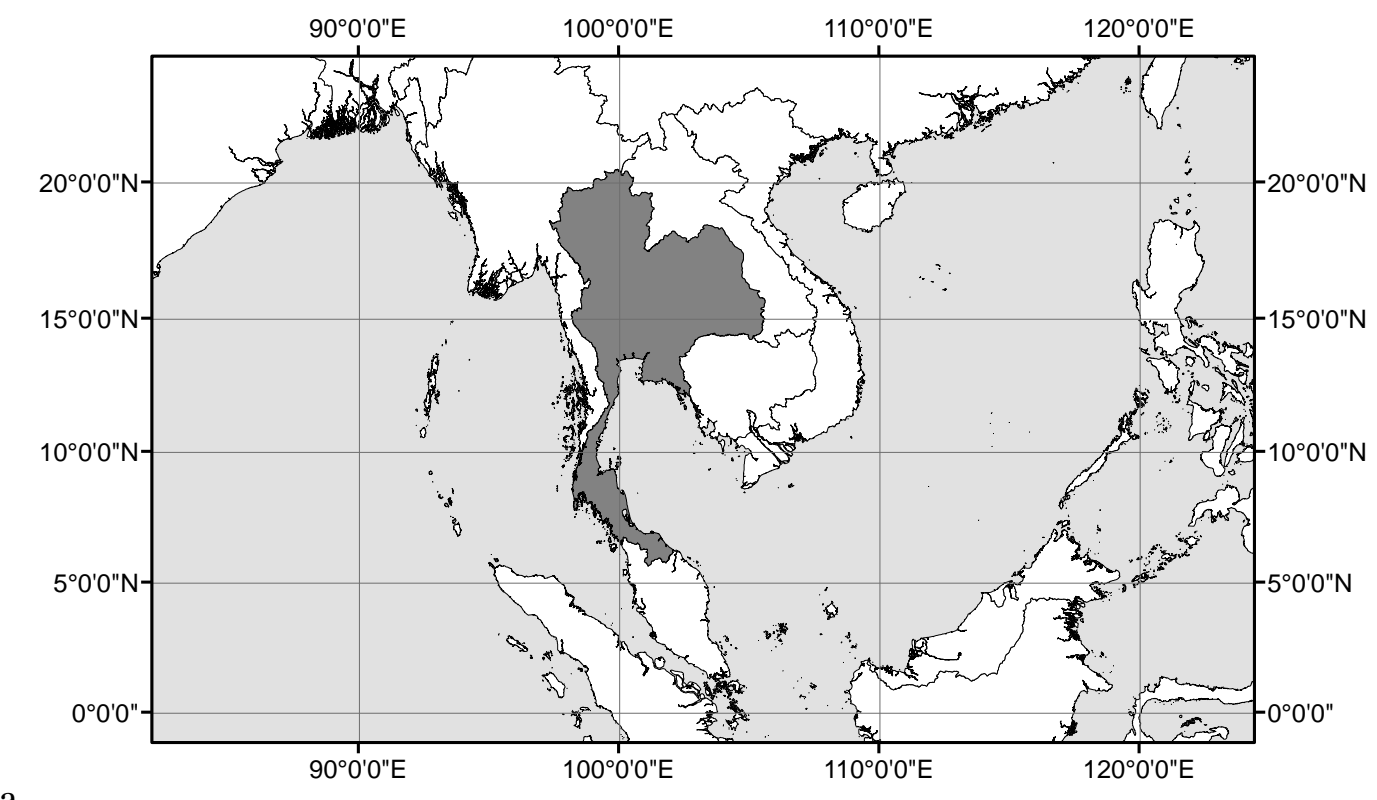

a. 


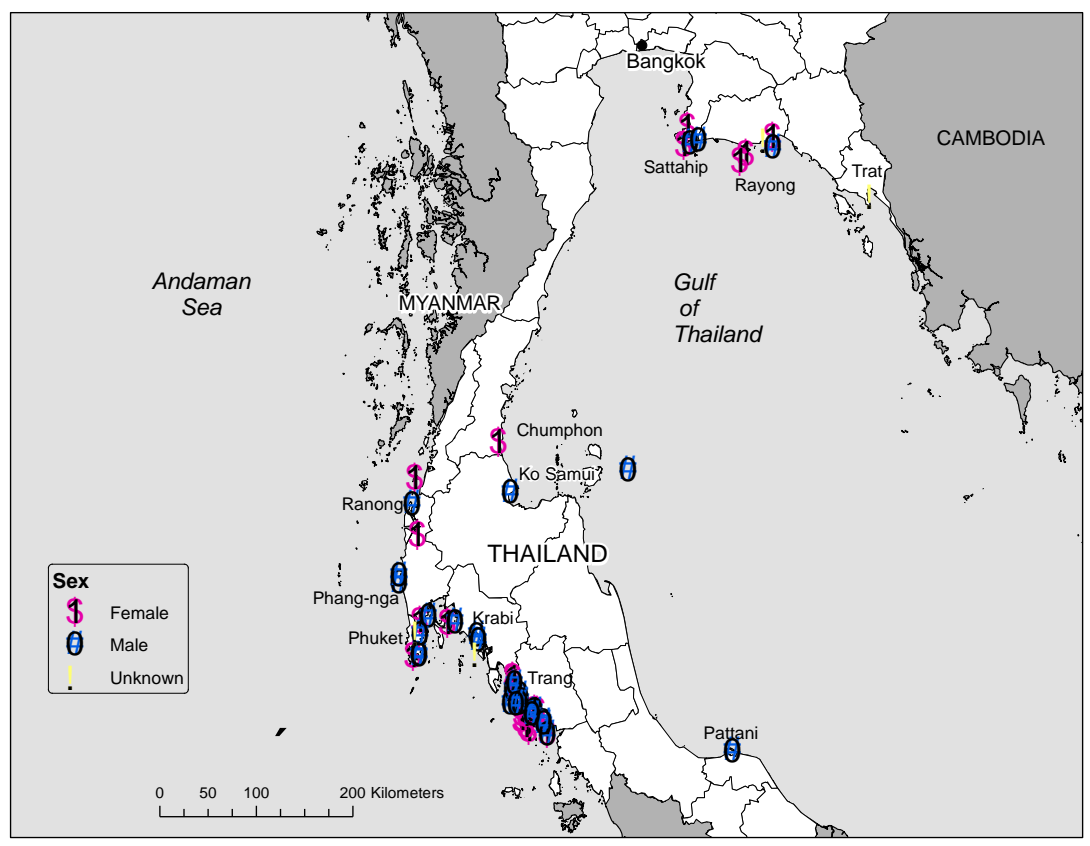

c.

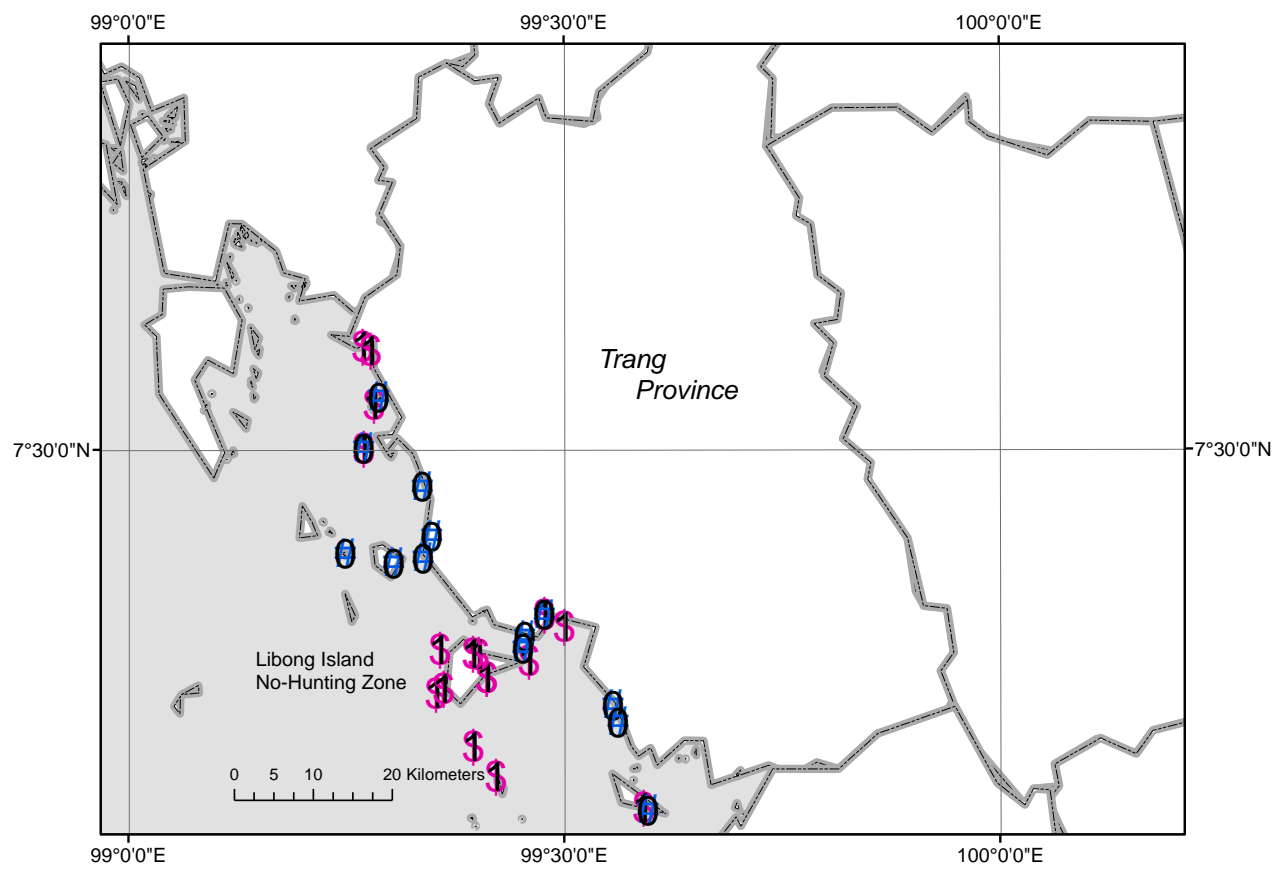

Figure 1a. Geographic map of Thailand. Points at which stranded dugongs were collected, within the Thailand region (b) and within Trang Province (c). 
Taking into account older influences on diversity, present day spatial variation in genetic markers inherently provides information reflective of a breeding-territory pattern within an organism's range. To date, population genetic research on dugong populations has focused primarily on the Australian region. Mitochondrial D-loop sequences (the replication promoter region of the mitochondrial circle, a maternally inherited genome) indicated two monophyletic clusters of haplotypes, one centered in western and one in eastern Australia with overlap of populations carrying both lineages in Torres Strait, between Australia and Papua New Guinea (McDonald, 2005; Tikel, 1997). Analysis of microsatellite loci indicated high gene flow throughout the region of northern Australia (McDonald, 2005). One explanation for this observation was that higher territoriality in females occurs over a long term, localizing the variation of the maternally inherited mitochondrial marker.

The dispersal potential of the dugong is apparently high; for example, single migrations of $1,000 \mathrm{~km}$ by male animals have been studied (Hobbs, 2007) and evidenced from anecdotal observations (reviewed in Sheppard et al., 2006). Tagging studies which have been conducted in Australia, indicate seagrass-localized foraging (Sheppard et al., 2010) but also relatively frequent macro migrations (reaching up to $625 \mathrm{~km}$ in one observed step) and which were also likely in either female or males in the QueenslandAustralia region (Sheppard et al., 2006).

In this study, mtDNA control region sequences and information from ten microsatellite loci and D-loop sequences developed for sirenians are employed. Samples were collected from both seas of the Kra Isthmus of Thailand (Andaman Sea and Gulf of 
Thailand) to test for a vicariance effect associated with the Malacca Strait which being as shallow as $25 \mathrm{~m}$ in places is intermittently barrier between the South China Sea and Indian Ocean. Using location information recorded for animals collected after stranding, the following hypotheses were tested. First, there may be geographically defined variation in D-loop sequences or microsatellites consistent with long-term philopatry to super-regions of sea grass habitat, rather than long distance dispersal homogenizing the gene pool over a large spatial scale. Secondly, the data were assessed to determine whether there are territorial differences between males and females observable as different aggregation patterns of male and female genotypes. Thirdly, while sampling is still limited and excludes vast regions, phylogenetic relationships of the presently available control region sequences on GenBank were summarized to assess effective dispersal at an oceanic scale. The data are relevant to determining whether dwindling populations of dugong found in Thailand should be managed as connected or as separate stocks and additionally elucidate population structure and dispersal patterns of dugongs in the region.

\section{Method}

\section{Study Site/Sample Collection}

Dugong tissue samples $(N=75)$ were collected at 11 localities in the coastal waters of Thailand from 1982-2008 (Rayong, Chonburi, Champorn, Surat-Thani, Pattani, Krabi, Phuket, Phang-nga, Trang, Ranong and Trat) by responding to reports of dead specimens (Table 1). 
Table 1. Records of stranded dugongs used in genetic analyses. U refers to unknown. Genetic marker indicates information obtained: cL and cR - left or right domains of the control region; $\mathrm{m}$ - ten microsatellite loci. Sample number followed by "fet" indicates fetus found with "mo" mother (ex. Du034fet and Du034mo).

\begin{tabular}{|c|c|c|c|c|c|c|c|c|c|}
\hline $\begin{array}{c}\text { Sample } \\
\text { name }\end{array}$ & Region & Location, Province & Latitude & Longitude & Sex & $\begin{array}{l}\text { Length } \\
\text { (m) }\end{array}$ & $\begin{array}{l}\text { Stranding } \\
\text { date if known }\end{array}$ & $\begin{array}{l}\text { Collection } \\
\text { date }\end{array}$ & $\begin{array}{l}\text { Genetic } \\
\text { Marker }\end{array}$ \\
\hline Du048 & Andaman Sea & Suksamran, Ranong & 9.486463 & 98.361992 & F & 2.71 & & Mar-03, 1996 & $\mathrm{cL}, \mathrm{cR}, \mathrm{m}$ \\
\hline Du029 & Andaman Sea & Kuraburi, Phang-nga & 9.244696 & 98.339668 & $\mathrm{M}$ & 1.31 & & Jul-15, 1994 & $\mathrm{cL}$ \\
\hline Du035 & Andaman Sea & Taimuang, Phang-nga & 8.508107 & 98.217534 & $\mathrm{M}$ & 1.55 & & Feb-05, 1995 & $\mathrm{cL}$ \\
\hline Du234 & Andaman Sea & Ko Yao, Phang-nga & 8.12474 & 98.66768 & $\mathrm{~F}$ & 2.57 & Apr-22, 2004 & Apr-23, 2004 & $\mathrm{cL}$ \\
\hline Du243 & Andaman Sea & Taimuang, Phang-nga & 8.572573 & 98.216589 & $\mathrm{M}$ & 2.75 & Dec-26, 2004 & Jan-19, 2005 & $\mathrm{cL}$ \\
\hline Du249 & Andaman Sea & Kuraburi, Phang-nga & 8.955986 & 98.388561 & $\mathrm{~F}$ & 2.00 & Aug-09, 2005 & Aug-10, 2005 & $\mathrm{cL}$ \\
\hline Du262 & Andaman Sea & Takuathung, Phang-nga & 8.144231 & 98.409112 & $\mathrm{~F}$ & 1.29 & & Feb-14, 2007 & $\mathrm{cL}, \mathrm{cR}, \mathrm{m}$ \\
\hline Du128 & Andaman Sea & Talang, Phuket & 8.021225 & 98.410137 & $\mathrm{U}$ & $\mathrm{U}$ & Oct-25, 2000 & Oct-26, 2000 & $\mathrm{cL}, \mathrm{cR}, \mathrm{m}$ \\
\hline Du232 & Andaman Sea & Talang, Phuket & 7.818541 & 98.348422 & $\mathrm{~F}$ & 1.15 & Feb-06, 2004 & Mar-05, 2004 & $\mathrm{cL}, \mathrm{cR}, \mathrm{m}$ \\
\hline Du268 & Andaman Sea & Talang, Phuket & 8.02369 & 98.41372 & $\mathrm{M}$ & 1.92 & Apr-02, 2007 & Apr-03, 2007 & $\mathrm{cL}, \mathrm{cR}, \mathrm{m}$ \\
\hline Du049 & Andaman Sea & Pu Island, Krabi & 7.831124 & 98.966461 & $\mathrm{U}$ & 2.25 & & Mar-09, 1996 & $\mathrm{M}$ \\
\hline Du070 & Andaman Sea & Norklong, Krabi & 8.014532 & 98.942709 & $\mathrm{M}$ & 2.00 & Aug-31, 1997 & Sep-01, 1997 & $\mathrm{cL}, \mathrm{cR}, \mathrm{m}$ \\
\hline Du1982 & Andaman Sea & Unknown location & c. 8.03 & c. 98.55 & $\mathrm{U}$ & $\mathrm{U}$ & & $\mathrm{U}$ & $\mathrm{cL}, \mathrm{cR}, \mathrm{m}$ \\
\hline Du226 & Andaman Sea & NorKlong, Krabi & 7.962681 & 98.956377 & $\mathrm{M}$ & 1.66 & & Jul-08, 2003 & $\mathrm{M}$ \\
\hline Du036 & Andaman Sea & Sikao, Trang & 7.617202 & 99.272136 & $\mathrm{~F}$ & 2.73 & & Mar-31, 1994 & $\mathrm{cL}, \mathrm{cR}, \mathrm{m}$ \\
\hline Du037 & Andaman Sea & Talibong Is., Kantang, Trang & 7.218182 & 99.355873 & $\mathrm{~F}$ & 1.70 & May-31, 1994 & Jul-27, 1994 & $\mathrm{cL}, \mathrm{cR}, \mathrm{m}$ \\
\hline Du051 & Andaman Sea & Kantang, Trang & 7.28334 & 99.457707 & $\mathrm{M}$ & 2.00 & Mar-23, 1996 & Jun-23, 1996 & $\mathrm{cL}$ \\
\hline Du052 & Andaman Sea & Sikao, Trang & 7.455745 & 99.340172 & $\mathrm{M}$ & 2.30 & & Mar-23, 1996 & $\mathrm{cL}$ \\
\hline Du057 & Andaman Sea & Kantang, Trang & 7.308151 & 99.48009 & $\mathrm{~F}$ & 2.56 & & Jan-02, 1997 & $\mathrm{cL}$ \\
\hline Du058 & Andaman Sea & Kantang, Trang & 7.308151 & 99.48009 & $\mathrm{M}$ & 2.50 & & Jan-06, 1997 & $\mathrm{cL}$ \\
\hline Du059 & Andaman Sea & Kantang, Trang & 7.398681 & 99.351283 & M & 2.45 & & Feb-14, 1997 & $\mathrm{cL}$ \\
\hline Du060 & Andaman Sea & HatSamran, Trang & 7.204325 & 99.559211 & $\mathrm{M}$ & 1.92 & & Mar-18, 1997 & $\mathrm{cL}, \mathrm{cR}, \mathrm{m}$ \\
\hline Du074 & Andaman Sea & Kantang, Trang & 7.378639 & 99.252102 & $\mathrm{M}$ & 2.06 & & Jan-25, 1998 & $\mathrm{cL}, \mathrm{cR}, \mathrm{m}$ \\
\hline Du075 & Andaman Sea & Sikao, Trang & 7.500238 & 99.273025 & $\mathrm{M}$ & 2.40 & & Mar-01, 1998 & $\mathrm{cL}$ \\
\hline Du103 & Andaman Sea & Talibong Is., Kantang, Trang & 7.262425 & 99.404925 & $\mathrm{~F}$ & 1.67 & & Jan-28, 1999 & $\mathrm{cL}, \mathrm{cR}, \mathrm{m}$ \\
\hline Du119 & Andaman Sea & Sikao, Trang & 7.559329 & 99.290423 & M & 1.53 & & Feb-05, 2000 & \\
\hline Du120 & Andaman Sea & Kantang, Trang & 7.374033 & 99.341465 & $\mathrm{M}$ & 1.51 & & Mar-07, 2000 & $\mathrm{cL}, \mathrm{cR}, \mathrm{m}$ \\
\hline
\end{tabular}




\begin{tabular}{|c|c|c|c|c|c|c|c|c|c|}
\hline Du126 & Andaman Sea & Talibong Is., Kantang, Trang & 7.255751 & 99.462723 & $\mathrm{~F}$ & 2.00 & & May-06, 2000 & \\
\hline Du129 & Andaman Sea & Sikao, Trang & 7.613017 & 99.28096 & $\mathrm{~F}$ & 2.25 & & Dec-06, 2000 & $\mathrm{cL}, \ldots \ldots \mathrm{m}$ \\
\hline Du143 & Andaman Sea & Kantang, Trang & 7.122202 & 99.424914 & $\mathrm{~F}$ & 1.99 & Nov-28, 2001 & Dec-19, 2001 & $\mathrm{cL}, \mathrm{cR}, \mathrm{m}$ \\
\hline Du144 & Andaman Sea & Kantang, Trang & 7.368041 & 99.307403 & $\mathrm{M}$ & 2.63 & Jan-08, 2002 & Jan-15, 2002 & $\mathrm{cL}, \mathrm{cR}, \mathrm{m}$ \\
\hline Du145 & Andaman Sea & HatSamran, Trang & 7.083366 & 99.598953 & $\mathrm{M}$ & 1.56 & Mar-08, 2002 & Mar-09, 2002 & $\mathrm{cL}$ \\
\hline Du219 & Andaman Sea & Kantang, Trang & 7.223214 & 99.364802 & $\mathrm{~F}$ & 1.0 & & Mar-09, 2003 & $\mathrm{cL}, \mathrm{cR}, \mathrm{m}$ \\
\hline Du227 & Andaman Sea & Hat Samran, Trang & 7.184221 & 99.564697 & $\mathrm{M}$ & 2.47 & Aug-10, 2003 & Aug-11, 2003 & $\mathrm{M}$ \\
\hline Du233 & Andaman Sea & Kantang, Trang & 7.15699 & 99.39893 & $\mathrm{~F}$ & 2.64 & Apr-20, 2004 & Apr-21, 2004 & M \\
\hline Du240 & Andaman Sea & Sikao, Trang & 7.500131 & 99.272937 & $\mathrm{~F}$ & 1.71 & Dec-06, 2004 & Dec-07, 2004 & $\mathrm{cL}$ \\
\hline Du241 & Andaman Sea & Sikao, Trang & 7.550382 & 99.284836 & $\mathrm{~F}$ & 2.29 & Dec-06, 2004 & Dec-07, 2004 & $\mathrm{cL}$ \\
\hline Du248 & Andaman Sea & Palien, Trang & 7.087115 & 99.594042 & $\mathrm{~F}$ & 1.91 & Aug-4, 2005 & Aug-06, 2005 & $\mathrm{cL}, \mathrm{cR}, \mathrm{m}$ \\
\hline Du260 & Andaman Sea & Talibong Is., Kantang, Trang & 7.263952 & 99.39851 & $\mathrm{~F}$ & 1.74 & & Jan-12, 2007 & $\mathrm{cL}, \mathrm{cR}, \mathrm{m}$ \\
\hline Du270 & Andaman Sea & Kantang, Trang & 7.269749 & 99.456007 & M & 1.6 & & Jul-06, 2007 & $\mathrm{cL}, \mathrm{cR}, \mathrm{m}$ \\
\hline Du151 & Gulf of Thailand & Yaling, Pattani & 6.924373 & 101.323928 & $\mathrm{M}$ & 1.40 & & Nov-15, 2002 & $\mathrm{cL}, \quad \mathrm{m}$ \\
\hline Du015 & Gulf of Thailand & Chaiya, Surat Thani & 9.356811 & 99.252138 & $\mathrm{M}$ & 0.9 & & Apr-24, 1993 & $\mathrm{cL}$ \\
\hline Du088 & Gulf of Thailand & Ko Samui, Surat Thani & 9.564451 & 100.349929 & M & 2.35 & & Aug-30, 1998 & $\mathrm{cL}, \mathrm{cR}, \mathrm{m}$ \\
\hline Du078 & Gulf of Thailand & Lamae, Chumphon & 9.826645 & 99.143202 & $\mathrm{~F}$ & 2.31 & & May-19, 1998 & $\mathrm{M}$ \\
\hline Du127 & Gulf of Thailand & Sattahip, Chonburi & 12.617072 & 100.869291 & $\mathrm{~F}$ & 1.08 & & Jun-13, 2000 & $\mathrm{cL}, \mathrm{cR}, \mathrm{m}$ \\
\hline Du244 & Gulf of Thailand & Sattahip, Chonburi & 12.634576 & 100.927209 & $\mathrm{M}$ & 2.09 & Feb-01, 2005 & Feb-15, 2005 & $\mathrm{cL}, \mathrm{cR}, \mathrm{m}$ \\
\hline Du250 & Gulf of Thailand & Sattahip, Chonburi & 12.777119 & 100.902797 & $\mathrm{~F}$ & 2.38 & Aug-21, 2005 & Aug-22, 2005 & $\mathrm{cL}, \mathrm{cR}, \mathrm{m}$ \\
\hline Du065 & Gulf of Thailand & Klaeng, Rayong & 12.652803 & 101.652067 & $\mathrm{U}$ & $\mathrm{U}$ & Dec, 1996 & Jan-27, 1997 & $\mathrm{cL}, \mathrm{cR}, \mathrm{m}$ \\
\hline Du098 & Gulf of Thailand & Klaeng, Rayong & 12.589124 & 101.697686 & $\mathrm{M}$ & 2.14 & Oct-14, 1998 & Oct-15, 1998 & $\mathrm{M}$ \\
\hline Du130 & Gulf of Thailand & BanChang, Rayong & 12.658264 & 101.005879 & $\mathrm{M}$ & 2.09 & Mar-06, 2001 & Mar-07, 2001 & $\mathrm{cL}$ \\
\hline Du136 & Gulf of Thailand & Klaeng, Rayong & 12.692199 & 101.696314 & $\mathrm{~F}$ & 2.08 & & May-10, 2001 & $\mathrm{cL}$ \\
\hline Du030 mo & Gulf of Thailand & Muang, Rayong & 12.526349 & 101.445508 & $\mathrm{~F}$ & 2.42 & & Oct-07, 1994 & \\
\hline Du030 foe & Gulf of Thailand & Muang, Rayong & 12.46 & 101.39 & U & U & & Oct-07, 1994 & cL \\
\hline Du242 & Gulf of Thailand & Klaeng, Rayong & 12.131155 & 102.641895 & $\mathrm{~F}$ & 2.06 & Dec-20, 2004 & Jan-09, 2005 & $\mathrm{cL}, \mathrm{cR}, \mathrm{m}$ \\
\hline Du215 & Gulf of Thailand & Muang, Trat & 9.486463 & 98.361992 & $\mathrm{U}$ & $\mathrm{U}$ & 1998 & 1998 & $\mathrm{cL}$ \\
\hline
\end{tabular}




\section{Extraction}

DNA was extracted using the Glass Milk Extraction protocol (Boyle \& Lew, 1995), and PCR amplification was used to identify samples yielding suitable DNA. Of the original 75 samples obtained from Phuket Marine Biological Center, only 60 produced DNA suitable for analysis.

\section{Control Region Primer Design and Amplification}

Previous population studies of the dugong mitochondrial control region were conducted by PCR using a mammal-universal forward primer, A24 (Kocher et al., 1989), and a dugong-specific reverse primer, A58 (Tikel, 1997). A24 is located in tRNA ${ }^{\text {PRO }}$ which neighbors the D-loop promoter region, and A58 is located in the relatively conserved region within the D-loop; the primers flank the hypervariable region 1 of mammalian control region (Greenberg et al., 1983; Tikel, 1997). McDonald (2005) and Murata et al. (2003) identified mismatches at the 5' ends of these primers with respect to a full dugong mitochondrial sequence and suggested the usefulness of further primer design. Therefore, a custom PCR primer set was developed for this study (Cipriano, personal communication).

Two additional PCR primers were designed: a forward primer Du-tRNA ${ }^{\mathrm{Thr}}\left(5^{\prime}\right.$ TTA CAA CGG TCT TGT AAA CCG 3'), which neighbors tRNA ${ }^{\mathrm{PRO}}$, and a reverse primer Du-tRNA $^{\text {Phe }}$ (5' AGG CAT TTT CAG TGC CTT GC 3'), which obtains the right domain of the control region. The primers were selected using Primer3 (Koressaar \& Remm, 2007) with reference to a published dugong mitochondrial genome (Arnason et 
al., 2002; GenBank: AJ421723), amplifying 1607 base pairs. tRNA configuration is conserved broadly in mammals suggesting Du-tRNA ${ }^{\text {Thr }}$ and Du-tRNA ${ }^{\text {Phe }}$ can be used widely. Amplifications were conducted using either primers A24-A58 or Du-tRNA ${ }^{\mathrm{PRO}}$, Du-tRNA $^{\text {Phe }}$ (Table 1). Sequences were lodged in NCBI GenBank (GenBank accession numbers: KJ022707-KJ022760.

PCR reactions were conducted in $25 \mu 1$ reaction volume, using Eppendorf MasterTaq Kit ${ }^{\circledR}$ PCR enzyme and 10x Reaction Buffer or GeneAmp ${ }^{\circledR}$ PCR Gold 10x buffer and AmpliTaq Gold DNA Polymerase (Applied Biosystems, Inc.) and reactions generally contained 2.0-3.0 mM MgCl2, $0.4 \mathrm{mg} / \mathrm{ml}$ bovine serum albumin (BSA), 2.5 $\mathrm{mM}$ dNTPs, $0.5 \mathrm{mM}$ forward and reverse primers, and 10-25 ng of DNA template. The PCR conditions for A24 and A58 primer amplification were described by Palmer (2004) as $96^{\circ} \mathrm{C}$ for $5 \mathrm{~min}, 30$ cycles of $\left(96^{\circ} \mathrm{C}\right.$ for $30 \mathrm{~s}, 45^{\circ} \mathrm{C}$ for $30 \mathrm{~s}, 72^{\circ} \mathrm{C}$ for $\left.60 \mathrm{~s}\right)$, and $72^{\circ} \mathrm{C}$ for 10 min. A 150 s $73^{\circ} \mathrm{C}$ extension step was used in the case of Du-tRNA ${ }^{\text {PRO }}$, - Du-tRNA ${ }^{\text {Phe }}$ PCR. Samples which proved difficult to amplify initially in this case, were then attempted using AccuPower ${ }^{\circledR}$ HotStart PCR PreMix (Bioneer, Inc.) using 20 ul reactions and previous thermocycler profile. Before sequencing, PCR primers were digested by ExoSAP-it protocol (Affymetrix). Sequencing was performed in both directions using Big Dye ${ }^{\circledR}$ labeling (Applied Biosystems Inc.). Trace files were read using Sequencher 4.5 (Gene Codes Corporation, Ann Arbor, MI) and aligned using ClustalW (Thompson et al., 2004) in Mega 5.0 (Tamura et al., 2011). 


\section{Microsatellite Amplification}

A panel of 20 microsatellites was selected from previously published Florida manatee and dugong primer sets consisting of 17 manatee-derived microsatellites (Garcia-Rodriguez et al., 2000; Pause et al., 2007; Tringali et al., 2008) and three derived for the dugong (Broderick et al., 2007). Ten loci ultimately were used based on their consistency for amplification in the Thailand population and their levels of polymorphism (Table 2).

Microsatellite PCR reactions were singly conducted in $13 \mu$ l volume, using GeneAmp® PCR Gold reaction mix, and $0.4 \mathrm{mg} / \mathrm{ml}$ bovine serum albumin (BSA), 2.4 $\mathrm{mM} \mathrm{MgCl} 2,1 \mathrm{mM}$ dNTPs, and $0.05 \mathrm{mM}$ of a flurophore-labeled primer (forward primers, Table 2) and $0.23 \mathrm{mM}$ of reverse unlabeled primer, and either AmpliqTaq Gold (Applied Biosystems, Inc.) or Ex-Taq (TaKaRa) polymerase. For the three dugongdesigned primer pairs, a reaction profile of $94^{\circ} \mathrm{C}$ for $10 \mathrm{~min}, 35$ cycles $\left(94^{\circ} \mathrm{C}\right.$ for $30 \mathrm{~s}, 58$ ${ }^{\circ} \mathrm{C}$ for $45 \mathrm{~s}, 72^{\circ} \mathrm{C}$ for $30 \mathrm{~s}$ ) followed by a final extension of $72{ }^{\circ} \mathrm{C}$ for $7 \mathrm{~min}$, and AmpliqTaq Gold DNA polymerase generally was used. For the six manatee-designed primers, Ex-Taq polymerase was used with a reaction profile using altered annealing temperatures in different cycles as follows - phase 1,10 cycles: $94^{\circ} \mathrm{C}$ for $30 \mathrm{~s}, 58^{\circ} \mathrm{C}$ for $45 \mathrm{~s}, 72^{\circ} \mathrm{C}$ for $30 \mathrm{~s}$; phase 2,15 cycles: $94^{\circ} \mathrm{C}$ for $30 \mathrm{~s}, 54^{\circ} \mathrm{C}$ for $45 \mathrm{~s}, 72^{\circ} \mathrm{C}$ for $30 \mathrm{~s}$; and phase 3,10 cycles: $94^{\circ} \mathrm{C}$ for $30 \mathrm{~s}, 50^{\circ} \mathrm{C}$ for $45 \mathrm{~s}, 72^{\circ} \mathrm{C}$ for $30 \mathrm{~s}-$ followed by a final extension at $72^{\circ} \mathrm{C}$ for $7 \mathrm{~min}$. Primer pair TmaKb60 followed the same cycle pattern but instead amplified in a $60^{\circ} \mathrm{C}$ to $52^{\circ} \mathrm{C}$ stepdown reaction profile, using 1 min each for denature, anneal, and extension in each cycle. 
Microsatellite PCR products were diluted 1:13 in $\mathrm{HiDi} \circledast$ buffer and fragment sizes determined by comparison of a GeneScan-400HD (High Density) ${ }^{\mathrm{TM}}$ Rox $^{\mathrm{TM}}$ labeled internal lane size standard (Applied Biosystems) using an ABI 3100 capillary sequencer. Dugong-designed primers generally showed stronger amplification and were diluted to as low as 1:20 prior to dilution with $\mathrm{HiDi}{ }^{\circledR}$. Analysis of the fluorescently labeled amplicons was performed using GeneScan Analysis 2.1 (Applied Biosystems). Over $50 \%$ of the samples were run twice to confirm genotypes, as a general measure to minimize allele scoring errors (Hoffman \& Amos, 2005; Taberlet et al., 1996). 
Table 2. Locus information and characteristics for the 10 microsatellite loci utilized in this study. Information measures: optimized annealing temperature (Tm) or primer pairs, microsatellite Polymorphic Information Content (PIC) number of alleles per locus $(\mathrm{Na})$, number of effective alleles $(\mathrm{Ne})$, and the observed and expected heterozygosity ( $\mathrm{Ho}$ and $\mathrm{He}$ ) and original author. The allele size range recorded is from this study. PIC values were calculated using Cervus (Kalinowski et al. 2007). Values of $\mathrm{Na}, \mathrm{Ne}, \mathrm{Ho}$, and He were generated in GenAlEx with a step by step option by population for codominant data (Peakall \& Smouse, 2006, 2012).

\begin{tabular}{|c|c|c|c|c|c|c|c|c|c|c|}
\hline Locus and citation & $\begin{array}{l}\text { Species } \\
\text { for } \\
\text { design } \\
\end{array}$ & Primer sequence $\left(5^{\prime}-3^{\prime}\right)$ & Repeat motif & $\begin{array}{l}\text { Allele size } \\
\text { range }\end{array}$ & $\begin{array}{l}\mathrm{Tm} \\
\left({ }^{\circ} \mathrm{C}\right)\end{array}$ & PIC & $\mathrm{Na}$ & $\mathrm{Ne}$ & Ho & $\mathrm{He}$ \\
\hline $\begin{array}{l}\text { DduB01 } \\
\text { (Broderick et al. } \\
\text { 2007) }\end{array}$ & Dugong & $\begin{array}{l}\text { F: FAM-CACTGTGGTGAAAAGGGACA } \\
\text { R:TTATTTGGCTTGGGACTTGG }\end{array}$ & $(\mathrm{TG})_{33}$ & $332-374$ & 58 & 0.739 & 6.667 & 3.914 & 0.674 & 0.698 \\
\hline$\underset{n}{\mathrm{DduB02}}$ & Dugong & $\begin{array}{l}\text { F: NED-AAACCCAAATCGGATCATGT } \\
\text { R: GCTGGGTTTTCCATTCTCAT }\end{array}$ & $(\mathrm{TG})_{33}$ & $198-224$ & 54 & 0.772 & 5.333 & 2.433 & 0.641 & 0.574 \\
\hline$\underset{n}{\mathrm{DduC05}}$ & Dugong & $\begin{array}{l}\text { F: NED-CCATTGGCATTACATTCGTG } \\
\text { R: TGTTGTTCCCTTCTGAAGCA }\end{array}$ & $(\mathrm{CA})_{27}$ & $218-230$ & 58 & 0.545 & 5.33 & 2.941 & 0.689 & 0.651 \\
\hline $\begin{array}{l}\text { TmaKb60 } \\
\text { (Pause et al. 2007) }\end{array}$ & Manatee & $\begin{array}{l}\text { F: FAM-TAGACACAGGCAAGCAGTGG } \\
\text { R: AAGAGTGAGCGGAGATGTGG }\end{array}$ & $(\mathrm{TG}) 4(\mathrm{CG}) 1(\mathrm{TG}) 12(\mathrm{CG}) 6$ & $222-238$ & 58 & 0.619 & 6.333 & 3.915 & 0.448 & 0.690 \\
\hline $\begin{array}{l}\text { TmaA04 } \\
\text { (Garcia-Rodriguez } \\
\text { et al. 2000) }\end{array}$ & Manatee & $\begin{array}{l}\text { F: HEX-GAACACAAGACCGCAATAAC } \\
\text { R: TGGTGTATCACTCAGGGTTC }\end{array}$ & $(\mathrm{CT})_{2}(\mathrm{GT})_{12} \mathrm{AT}(\mathrm{GT})_{7} \mathrm{AT}(\mathrm{GT})_{2}$ & $195-227$ & 60 & 0.688 & 6.667 & 3.647 & 0.596 & 0.724 \\
\hline $\begin{array}{l}\text { Tma-FWC03 } \\
\text { (Tringali et al. 2008) }\end{array}$ & Manatee & $\begin{array}{l}\text { F: NED-TCACGCTTGGCCTGCCTCTGCCG } \\
\text { R:CTGCAGGGACACCCGTTATGGCA }\end{array}$ & $(\mathrm{CTG})_{6} \mathrm{TT}(\mathrm{CTG})_{4} \mathrm{TT}(\mathrm{CTG})_{7}$ & $146-150$ & 58 & 0.548 & 3.000 & 2.635 & 0.941 & 0.618 \\
\hline$\underset{\prime \prime}{\text { Tma-FWC04 }}$ & Manatee & $\begin{array}{l}\text { F: FAM-GGTTGTTTCCAGTTTGGGGTTCT } \\
\text { R:CATGTCCTGTGATCCATAAATTCC }\end{array}$ & $(\mathrm{AC})_{12}(\mathrm{ATTT})_{4}$ & $175-211$ & 58 & 0.350 & 8.000 & 5.581 & 0.807 & 0.811 \\
\hline$\underset{\prime}{\text { Tma-FWC08 }}$ & Manatee & $\begin{array}{l}\text { F: HEX-CTTCACAGCCTCCTGCACATAAGC } \\
\text { R:GTTCAGGAGAGGTTGCCAGGTCA }\end{array}$ & $(\mathrm{AC})_{13}$ & $149-159$ & 58 & 0.856 & 4.333 & 2.339 & 0.507 & 0.555 \\
\hline$\underset{\prime}{\text { Tma-FWC11 }}$ & Manatee & $\begin{array}{l}\text { F: HEX-CTTCACAGCCTCCTGCACATAAGC } \\
\text { R:ATTACCCATCCAGCCACCCCTTAT }\end{array}$ & $(\mathrm{CA})_{17}$ & $123-127$ & 58 & 0.458 & 2.333 & 1.725 & 0.241 & 0.415 \\
\hline $\begin{array}{l}\text { Tma-FWC17 } \\
\text { " }\end{array}$ & Manatee & $\begin{array}{l}\text { F: NED-CGACAGCAGTTCTCAGATAG } \\
\text { R:ATCAGACTTCGGTGGTGAGC }\end{array}$ & $(\mathrm{GT})_{18}$ & 201-209 & 58 & 0.554 & 3.667 & 1.890 & 0.415 & 0.445 \\
\hline
\end{tabular}




\section{Mitochondrial Analyses}

Using an alignment of 1003 control region nucleotides, a Bayesian Tree was constructed using General Time Reversible parameters (GTR $+\mathrm{I}+\mathrm{G})$ in MrBayes v3.1.2 (Ronquist \& Huelsenbeck, 2003), following model selection through jModeltest 2.0 (Darriba et al., 2012). The control region alignment omitted a repeat-sequence region in the control region right domain. Sequences for 39 animals, including sequences obtained by Tikel (1997): T677 (Torres Strait), and McDonald (2005): B61 (Townsville), MD56 (Torres Strait), D3 (Moreton Bay), SW1 (Ashmore Reef), LEM1 (Philippines), in addition to a manatee (sample provided by Robert Bonde, USGS, Florida). A 410-base pair alignment of sequences of the left domain of the control region was used to constructed a parsimony haplotype network using TCS software (Clement et al., 2000) and used for population genetic analyses. Arlequin software (Excoffier \& Lischer, 2010) was used to calculate diversity indices including $h$ (the number and frequency of haplotypes) (Nei \& Tajima, 1981), $\pi$ (the average number of nucleotide differences per site in pair-wise comparisons among DNA sequences) (Nei, 1987), parameters of the mismatch distribution (Rogers \& Harpending, 1992) and the neutrality test indices, $D$ (Tajima, 1989) and $F_{\mathrm{S}}(\mathrm{Fu}, 1997)$. Analysis of molecular variance (AMOVA) was used to test for the presence of genetic structure among three regions: the northern area bordering the Thai Peninsula within the Andaman Sea, the adjacent area in the south within the Andaman Sea southern (Trang Province), and the Gulf of Thailand to the east of the Thai Peninsula. Statistical tests were conducted using 10,000 permutations in Arlequin. 


\section{Microsatellite Analyses}

Microsatellite polymorphic information content (PIC) was quantified using the program Cervus (Kalinowski et al., 2007) and polymorphism described using GenAlEx (Peakall \& Smouse, 2006, 2012). Tests for departure from Hardy-Weinberg equilibrium (HWE) were conducted in GenePop (version 4.1.3) (Raymond \& Rousset, 2012) using a Markov Chain method formula (dememorization 10,000, batches 100, iterations per batch 5000).

The level of polymorphism at the microsatellite loci was assessed by the observed $\left(H_{O}\right)$ and the expected $\left(H_{e}\right)$ heterozygosity, and the number of alleles per locus (Table 2) was calculated using GENALEX 6 (Peakall \& Smouse, 2006, 2012). $H_{O}$, is the actual amount of heterozygosity measured at a particular locus or population, whereas $H_{e}$ is the proportion of heterozygosity expected for a particular locus or population undergoing random mating and acting within Hardy-Weinberg equilibrium.

The consequence of a genetic bottleneck was tested using the program BOTTLENECK (Cornuet \& Luikart, 1997). Following a bottleneck, populations evolving under the infinite allele model will exhibit a reduction in the numbers of alleles $(k)$ and a later reduction in heterozygosity $(H)$ (Maruyama \& Fuerst, 1985). In BOTTLENECK a Wilcoxon-Sign Rank test was used to determine whether there was microsatellite loci showing heterozygosity excess. Of the three tests available in Bottleneck, the Wilcoxon test of heterozygosity excess was selected as the best fit, as it can be used successfully with the number of microsatellite loci and individuals in this study and presents reasonable power for testing for population declines (Cornuet \& 
Luikart, 1997, Peery et al., 2012). The two-phased model (TPM) was used as it is recommended for observing allele frequency data as described in McEachern et al. (2011) and parameters were defined as $90 \%$ of the mutations followed a stepwise model and $10 \%$ followed a multistep model with a variance of $\left(\sigma^{2} \mathrm{~g}\right)=12$ (Garza \& Williamson, 2001).

Tests for a reduction in M-ratio were also conducted using the program M_P_VAL (Garza \& Williamson, 2001) to calculate the M-ratio (M) statistic across all ten microsatellite loci and to compare this with an expected distribution generated from simulations under mutation-drift equilibrium (Garza \& Williamson, 2001). M, the ratio of the number of alleles $(\mathrm{K})$ to the range in allele size (r), for a sample of microsatellite loci can be used to detect reductions in effective population size using the formula $\mathrm{M}=$ K/r. Ideally bottlenecks should cause the population's number of alleles to decline faster than the range in allele size. The M-ratio of a bottleneck population should be smaller than stable wild populations that have an M value of 0.68 (Garza \& Williamson, 2001). The M-ratio program was run for all 10 loci and in each case dinucleotide repeats assumed. Pre-bottleneck theta (which is $4 \mathrm{x}$ effective population size $\mathrm{x}$ mutation rate) of 5 was chosen with $0.2 \%$ frequency of 3.5 step mutations (average size of mutations that are not one-step mutations) as recommended in the M_P_val default setting.

AMOVA (Analysis of Molecular Variance), considering fixation indices (the inbreeding coefficient within individuals relative to the subpopulation), was calculated using Arlequin software (Excoffier et al., 1992; Excoffier \& Lischer, 2010), examining 
partitioning among three regions - again, Trang Province, and the northerly areas of the Andaman coastline, and the Gulf of Thailand. Pairwise population differentiation indices were measured as infinite alleles distances (including $F_{\mathrm{ST}}$ ) and stepwise mutation distances $\left(R_{\mathrm{ST}}\right)$ (Slatkin, 1995) and tested using 10,000 permutations.

The program STRUCTURE 2.3.3 (Pritchard et al., 2000) was used to cluster individuals into populations on the basis of microsatellite genotypes without prior assumption as to population structure. STRUCTURE was run 20 times each for each K value from 1 to 10 using a burn in period of 10,000 followed by 50,000 iterations of Markov chain Monte Carlo with an admixture model. Structure Harvester (Earl \& vonHoldt, 2012) a Webserver implementing the Evanno et al. (2005) clustering algorithm determined an optimal value of $\mathrm{K}=7$.

\section{Results}

\section{Mitochondrial Diversity}

Genetic information was obtained from 62 stranded dugongs, 48 of which were collected from the Andaman Sea (30 of these from Trang Province) and 14 from the Gulf of Thailand (Table 1). In 27 cases, haplotypes were obtained for the entire control region. After removing an internal segment rich in a microsatellite-like (GCATAC) repeat, a Bayesian Tree was inferred from the control region sequences (using 1003 nucleotide sites, excluding inferred gaps), and includes 5' and 3' hypervariable domains. This tree $($ GTR + I + G model, Figure 2) had three clusters: 1 and 2, corresponding to a north-eastern Australian group of sequences (posterior probability of 60\%), sequences from the north Andaman set of Thailand dugongs ( $\mathrm{pp}=67 \%)$, and a more strongly 
supported grouping $(\mathrm{pp}=87 \%)$, referred to here as cluster 3. Cluster 3 included Gulf of Thailand and the north Andaman Sea Thailand region individuals, and two other individuals analyzed previously (McDonald, 2005) from in the west Indo-Pacific region: SW1, from Ashmore Reef), and LEM1, Philippines. 


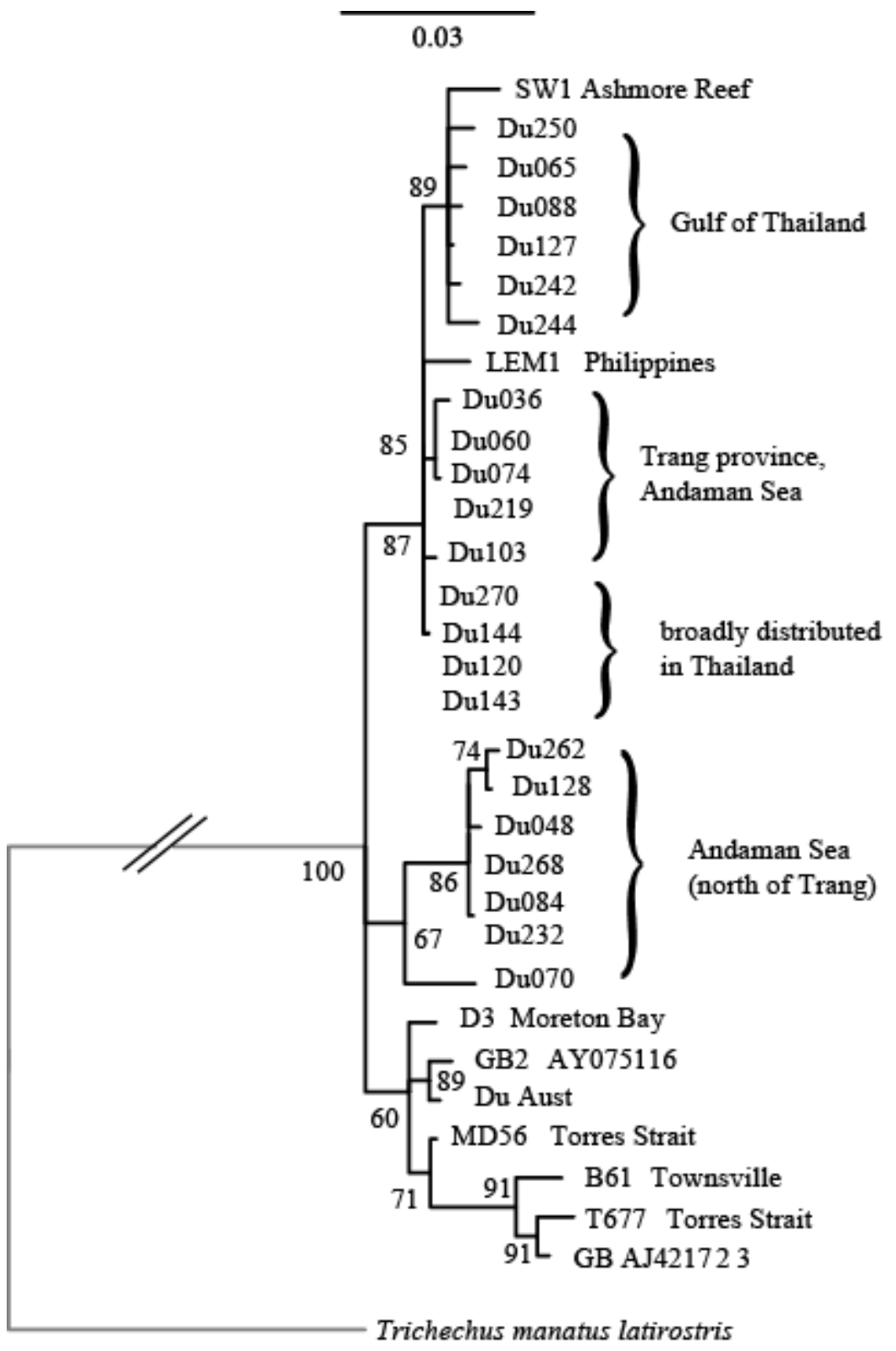

Figure 2. Bayesian tree of control region sequences of 31 dugong: $G T R+G$ model, 1003 nucleotide sites and 24 haplotypes. Posterior probabilities $>50 \%$ are shown at nodes. GB indicates GenBank entries of unknown source location. 
A 410-base pair segment from the 5' left domain, including the start of the control region (referred to as CR1), was the most widely available sequence for defining haplotypes. Sequences from 53 Thai region dugongs (Table 1), from bones of two specimens from Fort Frederik Hendrik, Mauritius deposited by Dutch colonists c. 400 BP (Haile, J. unpublished data, GenBank accessions: EU826002, EU826002) and from a skin sample from India (GenBank accession: EF057439, female, Jayasankar et al., 2009) were included in the analysis.

According to the parsimony network for control region 1 sequences (Figure 3) genetic clusters are not differentiated by region, indicating historic maternal dispersal over long distances. Twelve CR1 haplotypes were found in Thailand, of which seven were singletons. Of the remaining five, four haplotypes were specific for the population (north Andaman Sea, Trang, or Gulf of Thailand). Haplotypes from three regions of the parsimony network occurred in the more northern Andaman sea area of Thailand, while samples from the area to south, Trang Province, and Gulf of Thailand were comprised of Thai Haplogroup 1(TH1). The most common haplotype (TH1) occurred in the north Andaman Sea, Trang Province and Gulf of Thailand. 


\section{Legend}

- non-sampled hapotype

\section{Thai Region haplotypes:}

n. Andaman

Trang

Gulf of Thailand

\section{iland}

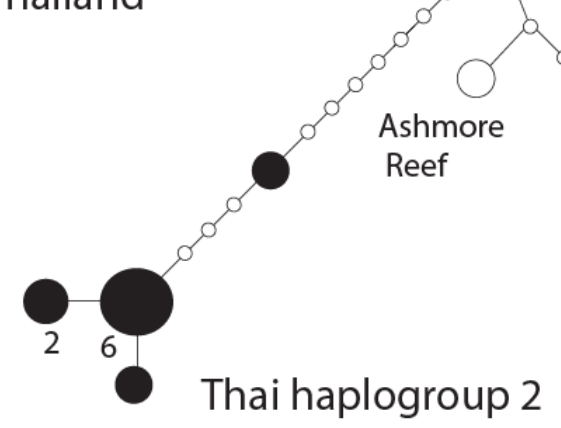

Philippines

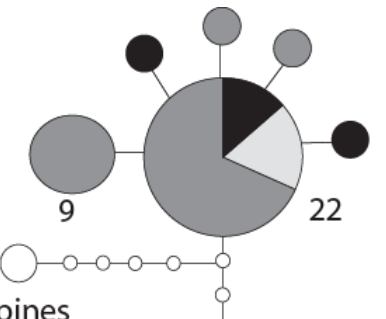

Thai haplogroup 1

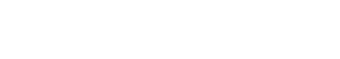

Fire 3. Parsimony network of 19 control region (left domain) haplotypes of 62 dugong. Connected lines and inferred haplotypes indicate regions of topology that were supported with $>90 \%$ confidence (connection limit=12 steps) under the TCS parsimony criterion. Connection between Torres Strait individuals was inferred by minimum spanning algorithm. Numbers next to circles are sample size; if no number is shown, $n=1$. 
In Thailand, the north Andaman Sea area CR1 haplotype pool was more diverse than the Trang Province and the Gulf of Thailand (Figure 3). Notably, a male of intermediate size, found in Krabi province in the north Andaman Sea region (haplotype of Du070), was more closely linked to an Australian and an India-Mauritius CR1 haplogroup, which is known from three specimens (Figure 3). The mitochondrial sequence divergence estimates for the Thailand population were $h=0.7779+/-0.0443$ and $\pi=1.2658+/-0.6845(\pi(\%)+/-\mathrm{SD} \%)$.

\section{Microsatellite Diversity}

Seven of the microsatellite loci have one or more populations out of the $p>0.05$ expectation for meeting Hardy-Weinberg Equilibrium (HWE) and two, FWC03 and FWC08, have two populations that do not meet the expectation. DduB01, DduC05 and Tma-FWC17 appear to be in HWE when individually analyzed (Table 3). 
Table 3. Probabilities reflecting fit of allele frequencies and Hardy-Weinberg proportion for microsatellite loci. Exact probabilities were estimated by a Markov chain method in GenePop (Raymond \& Rousset 1995). Values that are significant at $p<0.05$ are shown in bold.

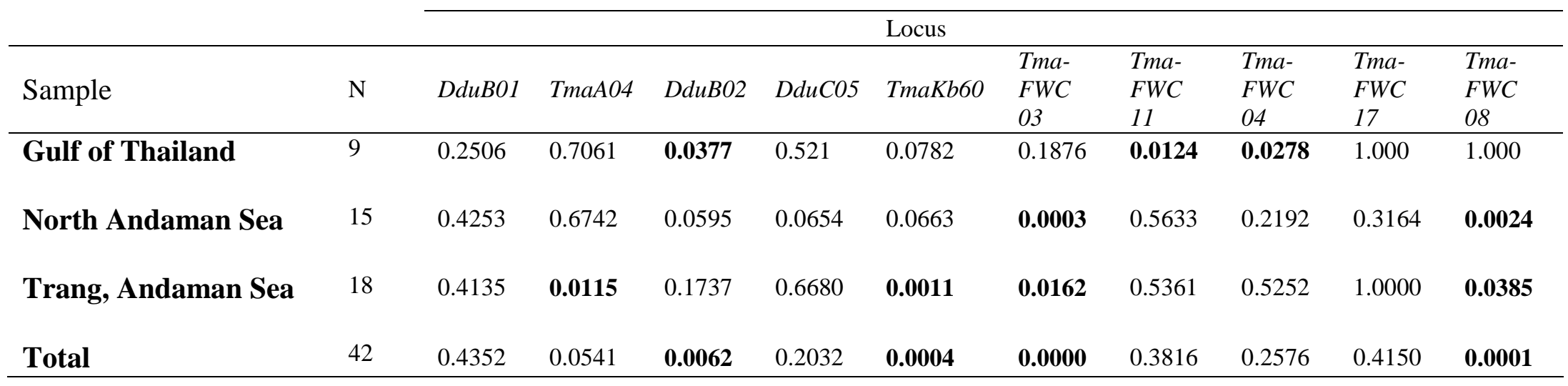


The mean for heterozygosity observed, $H_{\mathrm{O}}$, was 0.600 for the Gulf of Thailand, 0.593 for the north Andaman Sea, and 0.594 for Trang Province. These are compared with expected heterozygosities, $H_{e}$, of 0.607 for the Gulf of Thailand, 0.641 for the north Andaman Sea, and 0.606 for Trang Province. $F_{\text {is }}$ is the measure of deviation from panmictic frequency for heterozygosity deficiency or excess and also known as the inbreeding coefficient. Overall, $F_{\text {is }}$ was 0.055 , which was low, indicating that there was likely not significant inbreeding in the three subpopulations. The number of alleles $(\mathrm{Na})$ ranged from 4.7 to 5.5 (Table 2). The number of effective alleles $(\mathrm{Ne})$ is lower than the observed number of alleles for all three populations, though only slightly less in the Gulf of Thailand. The micrisatellite diversity was lower than seen in most mammalian populations, which usually have $\mathrm{He}=0.65$ and $\mathrm{Na}$ closer to 8 (DiBattista, 2007); however, the levels are actually higher than variation levels reported in populations of manatees (Kellogg, 2008). Individual loci values of the polymorphic information content (PIC) statistic, $\mathrm{Ho}$, and $\mathrm{He}$ were similar to, or slightly lower in some cases, to observed values in populations of Australian dugongs analyzed utilizing the same markers (Broderick et al., 2010; Kellogg et al., 2010).

\section{Population Structure Analysis}

Migrants in a population can be identified by multilocus microsatellite genotypes when an individual is assigned to a population based on genetic similarity but is actually collected within a different population (Frankham et al., 2002). STRUCTURE results 
analyzing groupings of microsatellite alleles (Figure 4) show that four individuals are grouped outside of their collection sites. Two individuals (\#Du151 a small male collected at Pattini Province in 2002 and \#Du088 a large male collected at Surat Thani in 1998) collected in the Gulf of Thailand appear to cluster more closely with the north Andaman Sea population. In addition, one individual stranded in Phuket (Du\#005 a small male collected at Phuket in 1982) appears to be more closely related to the Gulf of Thailand population than the north Andaman Sea population and one female stranded at Talibong Island, Trang Provence (Du\#260 collected in 2007) appears to be more genetically related to the Gulf of Thailand population. Three of the four individuals that fit outside of their collection site area were male and were collected several years apart. The lone female collected in Trang was a small female at 1.7 meters.

Comparing the mtDNA haplotypes of the four individuals grouping outside of their collection sites according to nDNA, there is evidence that two dugongs (\#Du151 and \#Du088 both males) were potentially descendants of a migrated male and a female with an endemic lineage to the Gulf region. Both had haplotypes specific to the Gulf of Thailand and closer microsatellite assignment to the Andaman population. A third individual, \#Du260 and a female, which was collected at Trang was assigned in genotype more strongly with the Gulf of Thailand population and had a widespread CR haplotype. The fourth individual (\#Du005 and male) did not have readable control region sequence. 


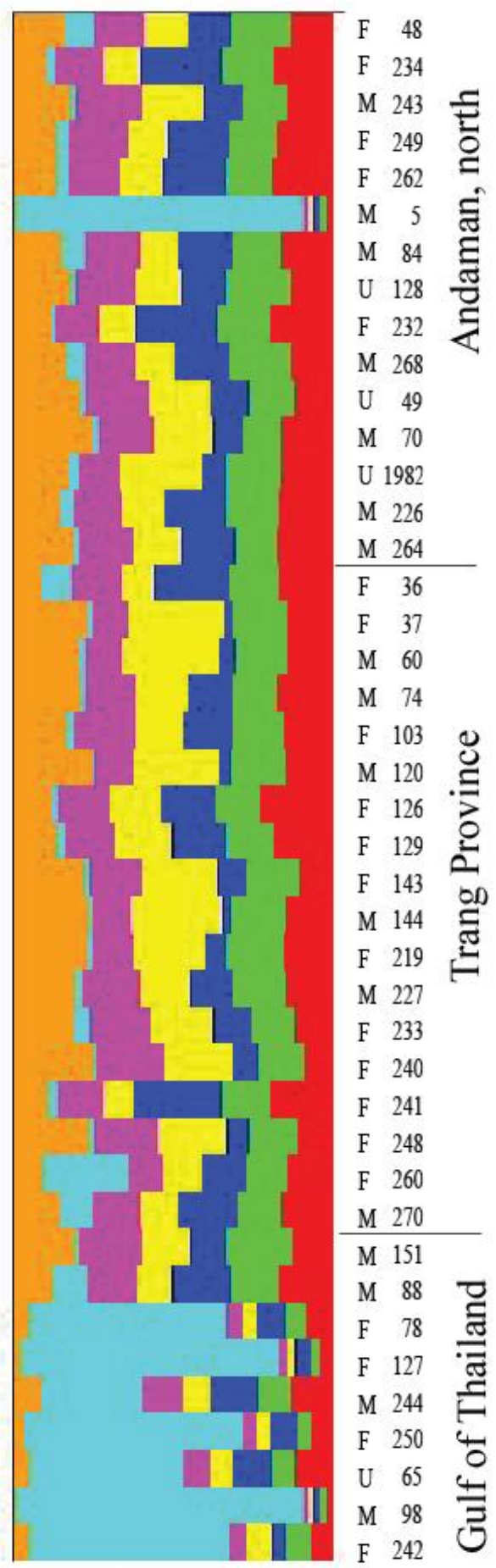

Figure 4. STRUCTURE diagram summarizing microsatellite genotype similarity and area of sampling. Specimen numbers refer to Table 1. Sex: M, F, or unknown (U). 
Table 4 is a comparison of $F$-statistic based tests for regional differentiation, showing $\phi$ distances for the haploid sequence marker, and Slatkin's $R_{\mathrm{ST}}$ for the microsatellites, along with the simpler allele-identity $F_{\mathrm{ST}}$ measures of differentiation. The CR1 data set considered for the Thailand samples strongly indicates regional differentiation (fixation indices for three populations overall: $\phi_{\mathrm{ST}}=0.6637$ and $\mathrm{p}<0.01$ ) with each of the pairwise comparisons among the Gulf of Thailand, north Andaman Sea, and Trang Province regions being significant. Differentiation was also seen in microsatellite alleles $\left(R_{\mathrm{ST}}=0.04227, \mathrm{p}=0.0002\right)$.

In considering the microsatellite data, $R_{\mathrm{ST}}$ indices were generally larger than $F_{\mathrm{ST}}$, with the exception of the pairwise comparison of the north Andaman Sea and Trang Province (Table 4). Given the context of the study, the relative difference in size $\left(R_{\mathrm{ST}}>\right.$ $\left.F_{\mathrm{ST}}\right)$ likely reflects the incorporation of novel mutations in the microsatellite alleles in approximate accordance with the stepwise mutation, and on the whole a paucity of gene flow in mixing these mutations. But possible scenarios are broad. Based on simulations (Hardy et al. 2003), a pattern of $R_{\mathrm{ST}}$ being considerably larger than $F_{\mathrm{ST}}$ arises when $m$, migration, is $<\mu$, the rate of new mutations, under the Island Model; or (for diverging populations, considering, $t$, the time since separation), $1 / t \leq \mu$; or thirdly, with stepping stone dispersal and multiple intervening populations. 
Table 4. Pairwise comparisons of genetic differentiation among the Gulf of Thailand, the northern Andaman Sea region and Trang. Top: Wright's standard $F_{\mathrm{ST}}$ comparisons (based on allele identity only). Lower: analogous genetic distance-based comparisons ( $\phi_{\mathrm{ST}}$ and $R_{\mathrm{ST}}$ ), for control region (left domain) sequences and microsatellites. In parentheses, P-values for AMOVA tests of no differentiation. Values of $p<0.05$ are highlighted. Differentiation measures are shown for the whole population and sexes separately to highlight possible movement differences.

\begin{tabular}{|c|c|c|c|c|c|c|}
\hline \multirow[t]{2}{*}{ Comparison } & \multicolumn{2}{|c|}{ Control region $\left(F_{\mathrm{ST}}\right)$} & \multicolumn{4}{|c|}{ Microsatellites $\left(F_{\mathrm{ST}}\right)$} \\
\hline & Population & $q$ & $\hat{0}$ & Population & $q$ & 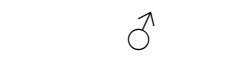 \\
\hline Gulf \& n. Andaman & $0.60718(<0.0001)$ & $0.4255(0.0047)$ & $0.0155(0.3348)$ & $0.02680(0.0578)$ & $0.0452(0.0108)$ & $0.0172(0.6258)$ \\
\hline n. Andaman \& Trang & $0.71405(<0.0001)$ & $0.3611(0.0020)$ & $0.0217(0.2999)$ & $0.02270(0.0239)$ & $-0.0022(0.5464)$ & $0.0415(0.1572)$ \\
\hline Comparison & \multicolumn{2}{|c|}{ Control region $\left(\phi_{\mathrm{ST}}\right)$} & \multicolumn{2}{|c|}{ Microsatellites $\left(R_{\mathrm{ST}}\right)$} & & \\
\hline Gulf \& n. Andaman & $0.6095(<0.0001)$ & $0.9190(0.0015)$ & $0.2480(0.0709)$ & $0.18122(0.0003)$ & $0.1624(0.0093)$ & $0.2376(0.0333)$ \\
\hline Gulf \& Trang & $0.6053(<0.0001)$ & $0.6417(0.0005)$ & $0.4101(\mathbf{0 . 0 3 3 2})$ & $0.12808(0.0003)$ & $0.1214(0.0160)$ & $0.1533(0.0800)$ \\
\hline n. Andaman \& Trang & $0.7160(<0.0001)$ & $0.95096(0.0002)$ & 0.4497 (0.0067) & $0.01857(0.1530)$ & $-0.0295(0.5442)$ & $0.0007(0.4582)$ \\
\hline
\end{tabular}


$R_{\mathrm{ST}}$ is calculated independently of mutation rate and calculated from the variance of allele sizes (Balloux \& Lugon-Moulin, 2002). $R_{\mathrm{ST}}$ values were closer to $R_{\mathrm{ST}}=0.15$ for Trang Province and north Andaman Sea compared to Gulf of Thailand, and is based on comparisons often a meaningful signal of differentiation between recently fragmented populations (Frankham et al., 2002). North Andaman Sea and Trang Province had an $R_{\mathrm{ST}}$ 0.01857 with $p<0.1530$ indicating higher geneflow as would be expected along this contiguous coastline.

The geographically neighboring populations of the north Andaman Sea and Trang also showed a reversed pattern of index contrast of $F_{\mathrm{ST}} \geq R_{\mathrm{ST}}$, both suggesting a greater level of gene flow. The north Andaman Sea and Trang Province areas had localized CR polymorphisms, and showed strong differentiation $\phi_{\mathrm{ST}}=0.7160(\mathrm{p}<0.0001)$. Localization of mitochondrial lineages suggests male dispersal mediates population differentiation at the nuclear loci. Examining the difference in CR matrices further revealed that the female-only group had higher segregation overall $\phi_{\mathrm{ST}}=0.9509(p<$ $0.0002)$, than male-only, $\phi_{\mathrm{ST}}=0.4497(p<0.0067)$, indicating also that instantaneous dispersal of males was greater.

\section{Diversity Level Comparisons and Tests of Historic Effects}

The haplotype diversity, $h$, is calculated by a function of number and frequency of haplotypes (Nei \& Tajima, 1981). The nucleotide diversity, $\pi$, is the average number of nucleotide differences per site in pair-wise comparisons among DNA sequences (Nei, 
1987). For Australian dugongs, $h$ was 0.96 (115 samples -492 bp) and $\pi=2.29(+1.16)$ (McDonald, 2005). For the Thailand dugong population as a whole, $h=0.7779$ and $\pi=1.26(+0.6845)$ (Table 5). Of the regional subgroups, the north Andaman Sea population had the highest haplotype diversity, $h=0.8462$ and nucleotide diversity, $\pi=1.5953(+0.8943)$ compared to Gulf of Thailand $(h=0.4848 ; \pi=0.3269(+0.2399))$ and Trang Province $(h=0.5983 ; \pi=0.1537(+0.1344))$.

If a population has recently undergone a bottleneck event or is experiencing a decline in population size, it will have a reduction in the allele numbers $(k)$ and in gene diversity $(\mathrm{He})$, though $\pi$ will likely not be reduced. Since $k$ will be reduced faster than other indices, the observed gene diversity will be higher than the expected gene diversity, Heq (Luikart \& Cornuet, 1998). In the BOTTLENECK program, utilization of the Wilcoxon test provides a high power test usable with small numbers of individuals (40 and under) and with 10 polymorphic loci according to the authors (Luikart and Cornuet, 1998). Bottleneck analysis using the Wilcoxon test suggested the possibility of a detectable change in allelic diversity due to a bottleneck in the north Andaman Sea population, and then only under the Stepwise Mutational Model (SMM). The probability of similarity compared with the infinite-neutral expectation under these conditions was 0.01611. However, the SMM analysis is a weak probability test and Two-Phased Model of mutation (TPM) is recommended with bottleneck tests for microsatellite analysis for strong evidence of a true bottleneck (Peery et al., 2012). TPM analysis produced a probability (one tail for $\mathrm{H}$ excess $)=0.90332$ which was not significant. Consequently, 
Table 5. Estimates of genetic diversity of the 5' end of the control region (445 base pairs) in Thailand dugong samples.

\begin{tabular}{|c|c|c|c|c|c|c|c|}
\hline Region & $\mathrm{N}$ & $\begin{array}{l}\text { Polymorphic } \\
\text { sites }\end{array}$ & $\begin{array}{l}\text { No. } \\
\text { haplotypes }\end{array}$ & $\begin{array}{l}\text { Haplotype diversity } \\
h \text { (SD) }\end{array}$ & $\begin{array}{l}\text { Nucleotide } \\
\text { diversity } \pi(\%) \\
\end{array}$ & $\begin{array}{l}\text { Tajima's } D \\
\text { (p-value) }\end{array}$ & Fu's $F_{\mathrm{S}}$ (p-value) \\
\hline Gulf of Thailand & 12 & 3 & 2 & $0.4848(0.1059)$ & $0.3269(0.2399)$ & $1.52266(0.9440)$ & $3.3537(0.93370)$ \\
\hline Northern Andaman Sea & 14 & 24 & 7 & $0.8462(0.0742)$ & $1.5953(0.8943)$ & $-0.25134(0.4353)$ & $1.5387(0.7705)$ \\
\hline Trang, Andaman Sea & 27 & 4 & 5 & $0.5983(0.0695)$ & $0.1537(0.1344)$ & $-0.90164(0.21450)$ & $-1.7502(0.0614)$ \\
\hline
\end{tabular}


we did not find evidence suggesting heterozygosity excess arising from a recent population decline.

The M-ratio test results were also not supportive of a bottleneck related change to microsatellite diversity. The program was run for all ten loci with dinucleotide repeats assumed and the M_P_val default settings. The resulting average $\mathrm{M}=0.7927$ was not significant when compared to the wild, stable population $M=0.68$. Due to the high $M$ there is no significant evidence of a bottleneck in the region wide data.

Fu's $F$ s test of selective neutrality for the entire data set of 53 control region sequences of 445 base pairs was positive and not significant with an $F$ s of 1.232 and a p-value of 0.713 (Table 5). However, it is notable that the Gulf of Thailand had $F \mathrm{~s}=$ 3.3537 since large positive values of $F$ s are evidence for a deficiency of alleles, as might be seen from a recent population bottleneck, though the p-value of 0.93370 .was not significant.

Tajima's D is a model test of mutation drift equilibrium and is often used to understand long-term changes in Ne by comparing the number of segregating sites in nucleotide diversity in DNA sequences (Tajima, 1989). Large, positive values of $D$ may indicate that a population may be decreasing or have experienced a potential bottleneck (Hunter, Auil-Gomez, et al. 2010; Kellogg, 2008; McDonald, 2005). Tajima's D = -0.17401 and non significant $(\mathrm{p}=0.45800)$ (Table 5) for the entire Thailand sample. The Gulf of Thailand ( $\mathrm{D}=1.52266$ ) was positive. Along with an observed Fu's $F \mathrm{~s}$ of 3.3537, this may indicate recent contraction of effective population size, or gene-level selection. is an influence on mtDNA variation in the Gulf of Thailand. 
Arlequin was used to explore spatial demographic expansion by creating a model with mismatch distribution using 5' control region sequences, the region containing the D-loop (Figure 5). If past population growth occurred as expected, the results should be in a characteristic wave shape; however, the observed results do not support that particular shape. Instead the pattern is of bimodal distribution, suggesting secondary contact or fusion of the population (Frankham et al., 2002).

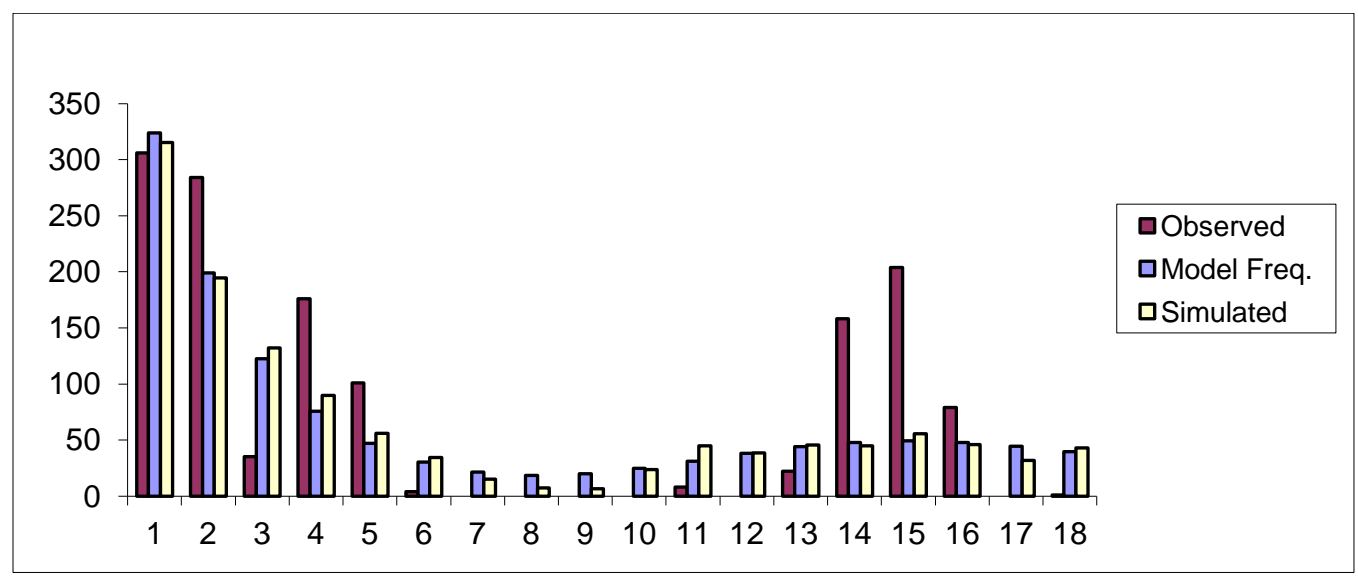

Figure 5. Spatial demographic expansion model. Observed and simulated data using the 5 ' control region sequences for mismatch distribution modeling in Arlequin (Excoffier \& Lischer, 2010).

\section{Discussion}

The dugong is vulnerable to extinction throughout its range. Due to the specific life history characteristics of dugongs, population simulations for a dugong population show that increases of more than 5\% per year are unlikely even under ideal conditions (Marsh et al., 1984). Therefore, the dugong is susceptible to population declines due to over-exploitation or demographic or environmental stochasticity (Frankham, 1995). 
Since dugongs are restricted to coastal habitats they are heavily impacted by human activities (Hines et al., 2012; Marsh et al., 2002). In Southeast Asia small, fragmented persistent populations remain. Approximately 250 dugongs are thought to remain in Thailand with one of the largest populations in Asia found in Trang Province at over 100 individuals (Adulyanukosol, 1999). In total, Andaman Sea is estimated to have 200 individuals (Hines et al., 2003, 2004) while the Gulf of Thailand's population is thought to be close to 50 individuals (Andulyanukosol, 2007; Andulyanukosol \& Thongsukdee, 2005, 2006).

In this study, mitochondrial control region sequences and information from ten microsatellite loci were utilized to test for geographically defined variation in D-loop sequences or microsatellites consistent with long-term philopatry to super-regions of sea grass habitat or long distance dispersal. The data were considered to establish whether there are territorial differences between males and females observable as different aggregation patterns of male and female genotypes. Phylogenetic relationships of the presently available control region sequences on GenBank were summarized to assess effective dispersal at an oceanic scale. The purpose being to determine whether dwindling populations of dugong found in Thailand should be managed as connected or as separate stocks and additionally elucidate population structure and dispersal patterns of dugongs in the region.

Nuclear DNA microsatellite markers developed for both manatee and dugongs were analyzed. Microsatellite DNA is inherited bi-parentally and therefore experiences recombination. Since both parents contribute to the offspring equally, the distinct 
combinations of microsatellites in a population will create a signature that can be distinguished from other populations (Kellogg, 2008; Murray, 1996). In the current, study, 10 microsatellites were selected that displayed allelic diversity and high heterozygosity was observed in all 10 microsatellites analyzed. These microsatellites have been used in a range of studies of manatee and dugong (Figure 6).

Seven of the loci have one or more populations out of the $p>0.05$ expectation for meeting Hardy-Weinberg equilibrium and two, FWC03 and FWC08, have two populations that do not meet the expectation. DduB01, DduC05 and Tma-FWC17 appear to be in HWE when individually analyzed. HWE occurs when the following standard assumptions are met: 1) the organism is diploid and reproduction is sexual, 2) generations are non- overlapping, 3) mating is random, 4) the population size is large, and 5) mutation, migration and selection are negligible (Frankham et al., 2002).

Dugongs are long-lived mammals with a generation time of around 27 years (McDonald, 2005). Dugongs accordingly violate assumptions of non-overlapping generations due to life span, and furthermore have lek mating behavior, based on research Western Australian populations (Anderson, 1997; McDonald, 2005). This may explain why many of microsatellite loci did not conform to Hardy-Weinberg Equilibrium (Table $3)$.

In the Thailand dugong population, additional violations of HWE are most likely the assumptions that the population size is effectively infinite and that mating is random in the population. Both are especially relevant to the Gulf group which is very small and spread out to such an extent that there may be limited ability to find mates. Though gene 
frequencies should be changing continuously to facilitate evolution on a larger scale, the small population in the Gulf likely has selection acting on it due to its small size and limited migration.

Utilizing the mitochondrial control region, 27 haplotypes were found in Thailand and group into three clusters (haplogroups)- Thai Haplogroup 1 (TH1), Thai Haplogroup 2 (TH2), and Thai Haplogroup 3 (TH3). TH1 was determined to be of mixed origin and included individuals from north Andaman Sea, Trang Province, the Gulf of Thailand, and the Philippines. TH2 was a single origin haplogroup found only in the north Andaman Sea. TH3 was also a mixed origin group and included an interesting mix of individuals from India, Mauritius, Australia, Torres Strait, and a single north Andaman specimen. With the exception of the TH2 haplogroup, the mitochondrial data indicates significant mixing of maternal lineages. Genetic clusters are not differentiated by region indicating maternal dispersal over long distances. 


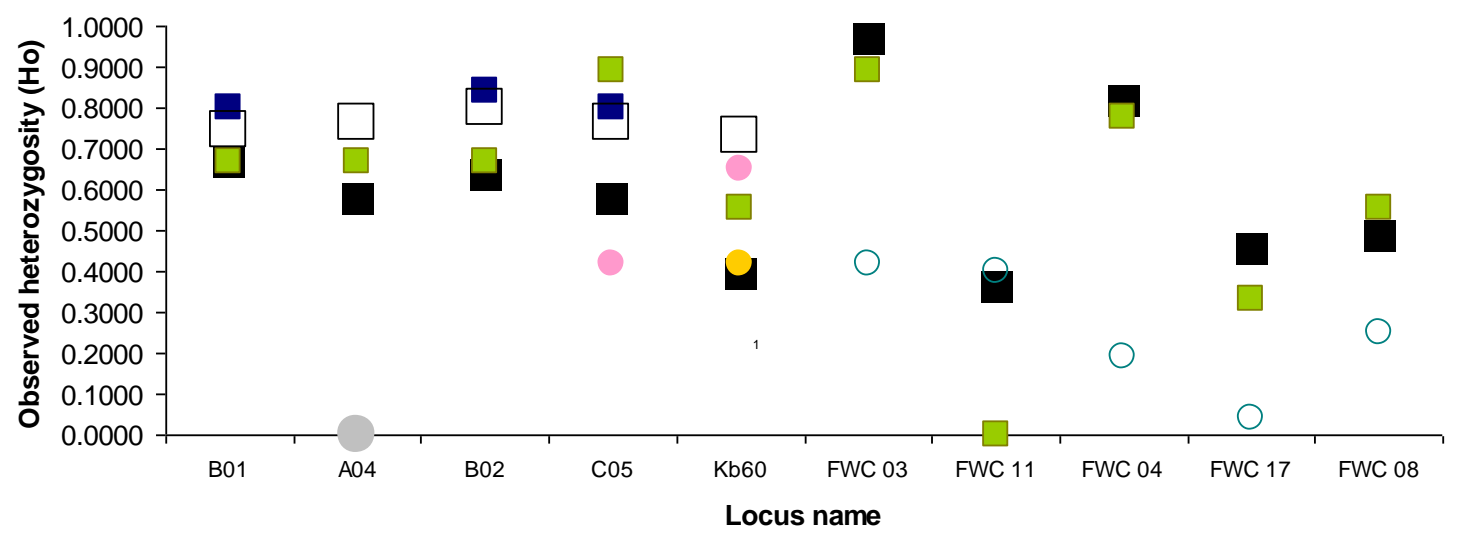

- Manatee Florida - Pause et al. 2007

- Dugong Australia - Broderiock et al. 2007

- Manatee Florida - Garcia-Rodriquez et al. 2000

Dugong - Andaman Sea,Thailand

- Manatee Florida - Kellogg et al. 2009

$\square$ Dugong - Gulf of Thailand

- Manatee Belize - Hunter et al. 2011

$\square$ Dugong Australia - Kellogg et al. 2009

○ Manatee Florida - Tringali et al. 2007

Figure 6. Observed heterozygosity for nuclear DNA microsatellite markers developed for both manatee and dugongs.. Marker variation is somewhat dependent on species (manatee populations were less diverse than dugong), and strongly dependent on the particular locus (i.e., genomic region).

One of the most significant elucidations that can arise from comparison of nuclear gene data and maternally inherited mitochondrial genomes is evidence of contrast in male and female dispersal. Analysis of microsatellite data shows a migration pattern does exist between the two sides of the Thai peninsula, especially in regards to male migration.

STRUCTURE analysis (Earl \& vonHoldt, 2012) grouped four out of 42 samples, 3 male and 1 female, outside of their collection sites. Comparing the nDNA findings to mtDNA, 2 males are potentially descendants of a migrated male with an endemic female, indicating a signal of dispersal between populations. 
Evidence of males dispersing while female lineages remain endemic to the regions was found in studies of dugongs of Australia (McDonald, 2005). Australian dugongs have been documented making long distance migrations of up to $625 \mathrm{~km}$ (Sheppard et al., 2006) and male manatees in Florida have frequent warm season distance travel that coincide with reproductive cycling (Marsh et al., 2012). Additionally there are rare events where dugongs make longer, deep-water crossings evidenced by the presence of Asian haplotypes in Australian dugong populations (McDonald, 2005) and anecdotal evidence of dugongs crossing deep-water trenches and travelling distances greater than $1000 \mathrm{~km}$ (Sheppard et al., 2006). Though the journey from the Andaman Sea to the Gulf involves a long distance migration around the Malaysian peninsula, it appears to be an event that does occur based on evidence in this study.

The neighboring areas of the north Andaman Sea and Trang Province support a persistent difference in average dispersal neighborhoods of male and female dugongs. Although it is difficult to assess with the current number of samples, both males and females may disperse over $100 \mathrm{~km}$ (Sheppard et al., 2006). Dispersal in a single generation may explain the presence of a novel haplotype group that nevertheless clusters within the known CR sequence tree of globally sampled dugongs; however, identification of a source population requires further sampling over the range of dugongs to establish the likely distance of dispersal events. Alternatively, a sharp phylogeographic break may lie to west of the Thai region, an area including India and Maldivian Island chains, and Oman-Persian Gulf and greater east African coastline. 
There was strong differentiation between the Gulf of Thailand and north Andaman Sea and between the Gulf of Thailand and Trang Province populations through pairwise comparison of microsatellite alleles, and no substantial differentiation of Trang Province and the north Andaman Sea populations. Statistical tests of microsatellite variation suggest three potential situations. First that novel mutations may have appeared in Thai populations at a rate faster than migrations can occur among these groups, so low gene flow exists between populations; or, that the time since populations were separated is greater than the mutation rate; or, there is a stepping stone type dispersal with multiple intervening populations.

$F$ statistic based tests on the control region strongly support regional differentiation in genotypes. However, in contrast north Andaman Sea and Trang Province show strong differentiation and conserved CR polymorphisms, which suggests male mediated dispersal. This is supported by gender specific CR matrix analysis, which shows that female-only groupings demonstrate higher CR segregation.

Only one weak signal of a bottleneck exists in the Thailand dugong population. Utilizing SMM with one tail for heterozygosity excess produced a probability of 0.01611 for the north Andaman Sea population but the use of SMM is not considered a robust test for microsatellites. Additionally, the M-ratio test did not support the idea of a bottleneck event. A negative result for the bottleneck test does not entirely eliminate the potential for a bottleneck event, just that the phenomenon is not readily measured by the test. Populations could have gone through a bottleneck event and be experiencing negative impacts on the population, such as inbreeding depression and loss of genetic diversity, 
long before the signal can be detected by the bottleneck tests currently available (Peery et al., 2012). However, though there were negative bottleneck test results, the Fu's Fs and Tajima's D tests indicate possible population decline in the region, especially pertaining to the Gulf of Thailand. McEachern et al. (2011) found that bottleneck tests appeared to suffer from small sample sizes and that caution should be used in attempting to detect bottlenecks in wild populations without adequate sampling.

\section{Regional Population Structure}

The north Andaman population has the highest haplotype diversity, which may indicate that this population is the oldest and may suggest a historic north to south dispersal. In this case, Gulf populations could be considered further extensions of this ancient migration (around the peninsula). Palmer (2004) suggested that dugongs entered the Thai region from the west and were confined to the Andaman Sea region during the last glacial maximum. Due to geographical barriers there was a lack of migration corridors and therefore no dispersal until sea levels rose to allow access around the Malaysian Peninsula.

However, according to the control region median spanning network (Figure 3), there does appear to be a signal from the east with individuals from the Philippines and Australia populations grouping with individuals from the all regions in the TH1 haplogroup. The grouping of the Indian and Mauritius samples confuses this slightly but clarification may come with the inclusion of additional dugong samples from throughout the region. 
A third explanation could be that the north Andaman Sea population is a remnant or refuge of the historic, Indo-Pacific spanning population and is still carrying its diversity signal. In this case, the Gulf of Thailand population is made up of more recent migrations from the east. This idea is supported by the results of the mismatch distribution analysis (Figure 5), which hints at migrations from two diverged populations

\section{Conclusions}

Dugong distribution is constrained by seagrass availability (Sheppard et al., 2006). The Gulf of Thailand population is thought to be small, with a total population estimate to be under 50 individuals (Andulyanukosol, 2007; Andulyanukosol \& Thongsukdee, 2005, 2006). In accordance the Gulf of Thailand population has low genetic diversity when compared to the two Andaman Sea populations (Trang Province and north Andaman Sea), especially the latter which has $\pi$ of $1.5 \%$ and an $h=0.8462$. The Gulf's low diversity may be due to a naturally low occurring population and could be a result of low seagrass populations and a pronounced seasonal change in the species and distribution of the grasses (Andulyanukosol \& Poovachiranon, 2006). This is in stark contrast to the Andaman Sea that has over $40 \%$ of its seagrass meadows in good condition, with abundant seagrass beds (Andulyanukosol \& Poovachiranon, 2006). Trang Province has the largest existing population of dugong and largest and healthiest seagrass meadows in the country (Adulyanukosol \& Thongsukdee, 2005; Hines, 2002; Hines, et al. 2005) with at least 11 species present (Andulyanukosol \& Poovachiranon, 2006). 
Site fidelity and knowledge of local seagrass beds is thought to be passed down from cow to calf (Anderson, 1979) and passing this habitat knowledge on to calves in healthy seagrass areas may limit the urge to migrate when they are adults. Philopatry may then be an important factor in differentiation of populations, even those existing close together (Palmer, 2004). Healthy seagrass protects the dugongs from stochastic events (such as the 2004 tsunami). With plenty of food and a protected environment, the dugongs of Trang may not frequently migrate out of the area creating a separation of that group from the neighboring dugongs. McDonald (2005) hypothesized that in Australia there may be a higher territoriality in females over a long time period localizing variation of the maternally inherited mitochondrial marker. The delineation between neighboring groups of dugongs in Thailand is supported by the conserved CR polymorphisms and Fst results between the north Andaman Sea and Trang Province indicating differentiation at the mitochondrial level. However, though dugongs in Trang seem to be separated genetically from its neighbors, dugongs can and do move from one location to another with limited frequency (Sheppard et al., 2006). Microsatellite Rst results indicate less differentiation between the neighboring populations than mtDNA. This is likely indicative of nuclear gene flow by male migration. Male migration is further supported when male and female CR $\phi$ are considered (Table 4). The signal of migration shown in STRUCTURE using nDNA further supports the hypothesis that there is male mediated gene flow with individuals found outside of their expected population but with mtDNA aligning with endemic lineages. From the current perspective, which to be conservative 
and cautious is still based on small population sizes and the use of limited genetic loci, male dispersal appears to be an important factor for regional divergence.

The data presented through this study show that there is high potential for dugong migration around the Malaysian peninsula and that dispersal in the region occurs. Therefore, populations of dugong found in Thailand should be managed as connected stocks to maintain current levels of genetic diversity. As with dugongs throughout the world, there is still much that is unknown about the Thailand population which would benefit from additional genetic studies to elucidate some of the intriguing questions about population origin, levels of migration, site fidelity and population structure in the region that have been touched upon in this study. At a larger scale, sampling to complete global phylogeography would be informative. Genetic comparison of Indian Ocean basin dugong populations in particular could provide important historical population data and illuminate the evolution of the populations in the region, notably in regards to Thai Haplogroup 2 that was found only in the north Andaman Sea region. 


\section{References}

Anderson, P. K. (1979). Dugong behaviour: on being a marine mammalian grazer. The Biologist, 61, 113-144.

Anderson, P. K. (1997). Shark Bay dugongs in summer: Lek mating. Behavior, 134(5/6), 433-462.

Adulyanukosol, K. 1999. Dugong, dolphin and whale in Thai waters. In Proceedings of the $1^{\text {st }}$ Korea-Thailand Joint Workshop on Comparison of Coastal Environment: Korea-Thailand. Seoul, South Korea.

Adulyanukosol. K., \& Thongsukdee, S. (2005). The results of the survey on dugong, dolphin, sea turtle, and seagrass in Trang Province. Phuket Marine Biological Center, Department of Marine and Coastal Resources. Bangkok, Thailand.

Adulyanukosol. K., \& Thongsukdee, S. (2006). Dugong (Dugong dugon) and seagrass in Thailand: Present status and future challenges. In Proceedings of the $7^{\text {th }}$ SEASTAR Workshop. Bangkok, Thailand.

Arnason, U., \& Janke, A. (2002). Mitogenomic analyses of eutherian relationships. Cytogenetic and Genome Research, 96(1-4), 20-32.

Balloux, F., \& Lugon-Moulin. N. (2002). The estimation of population differentiation with microsatellite markers. Molecular Ecology, 11, 155 -165.

Boyle, J. S., \& Lew, A. M. (1995). An inexpensive alternative to glassmilk for DNA purification. Trends in Genetics, 11, 8.

Broderick, D., Ovenden, J., Slade, R., \& Lanyon, J. M. (2007). Characterization of 26 new microsatellite markers in the dugong (Dugong dugon). Molecular Ecology Notes, 7, 1275-1277.

Clement, M., Posada, D., \& Crandall, K. A. (2000). TCS: a computer program to estimate gene genealogies. Molecular Ecology, 9, 1657-1660.

Cornuet J. M., \& Luikart G., (1997). Description and power analysis of two tests for detecting recent population bottlenecks from allele frequency data. Genetics, 144, 2001-2014.

Darriba, D, Taboada G. L., Doallo R., \& Posada D. (2012). jModelTest 2: more models, new heuristics and parallel computing. Nature Methods, 9(8), 772. 
DiBattista, J. D. (2007). Patterns of genetic variation in anthropogenically impacted populations. Conservation Genetics, 9, 141-156.

Earl, D. A., \& vonHoldt, B. M. (2012). STRUCTURE HARVESTER: a website and program for visualizing STRUCTURE output and implementing the Evanno method. Conservation Genetics Resources, 4(2), 359-361.

Evanno, G., Regnaut, S., \& Goudet, J. (2005). Detecting the number of clusters of individuals using the software STRUCTURE: a simulation study. Molecular Ecology, 14, 2611-2620.

Excoffier, L., \&. Lischer, H.E.L. (2010). Arlequin suite ver 3.5: A new series of programs to perform population genetics analyses under Linux and Windows. Molecular Ecology Resources, 10, 564-567.

Frankham R. (1995). Conservation Genetics. Annual Review of Genetics, 29, 305-327.

Frankham R., Ballou, J.D., \& Briscoe, D.A. (2002). Introduction to Conservation Genetics. Cambridge, United Kingdom: Cambridge University Press.

$\mathrm{Fu}$, Y. (1997). Statistical tests of neutrality of mutations against population growth, hitchhiking and background selection. Genetics, 147, 915-925.

Garcia-Rodriguez, A. I., Moraga-Amador, D., Farmerie, W., McGuire, P., \& King, T. L. (2000). Isolation and characterization of microsatellite DNA markers in the Florida manatee (Trichechus manatus latirostris) and their application in selected Sirenian species. Molecular Ecology, 9, 2155-2234.

Garza, J. C., \& Williamson, E. G. (2001). Detection of reduction in population size using data from microsatellite loci. Molecular Ecology, 10(2), 305-318.

Hardy, O. J., Charbonnel, N., Fré ville, H., \& Heuertz, M. (2003). Microsatellite allele sizes: A simple test to assess their significance on genetic differentiation. Genetics, 163, 1467-1482.

Heinsohn, G. E., Wake, J., Marsh, H., \& Spain, A. V. (1977). The dugong (Dugong dugon (Muller)) in the seagrass system. Aquaculture, 12, 235-248.

Hines, E. (2002). Conservation of the Dugong (Dugong dugon) along the Andaman Coast of Thailand: An example of the integration of conservation and biology in endangered species research. PhD dissertation. British Columbia, Canada: University of Victoria.

Hines, E., Adulyanukosol, K., \& Charuchinda, M. (2003). Population and habitat 
assessment of dugong (Dugong dugon) on the eastern of the Gulf of Thailand. In Final Report submitted to the Ocean Park Conservation Foundation. Hong Kong and Aberdeen, Australia.

Hines, E., Adulyanukosol, K., Charuchinda, M., Somany, P., \& Sam Ath, L. (2004). Conservation of dugongs (Dugong dugon) along the Eastern Gulf of Thailand in Thailand and Cambodia. Final Report to Ocean Park Conservation Foundation and Project Aware. Hong Kong and Aberdeen, Australia.

Hines, E., Adulyanukosol, K., \& Duffus, D.A. (2005). Dugong (Dugong dugon) abundance along the Andaman Coast of Thailand. Marine Mammal Science, 21(3), 536-549.

Hines, E., Adulyanukosol, K., Poochaviranon, S., Somany, P., Ath, L.S., Cox, N., Symington, K., Tun, T., Ilangakoon, A., de Iongh, H.H., Aragones, L.V., Lu, S., Jiang, X., D’souza, E., Patankar, V., Sutaria, D., Jethva, B., \& Solanki, P. (2012). Dugongs in Asia. In E. Hines, Reynolds, J., Mignucci-Giannoni, A., Aragones, L., \& Marmontel, M. (eds.), Sirenian Conservation: Issues and Strategies in Developing Countries (pg 58-76). Gainesville, Florida: University Press of Florida.

Hobbs, J. P. A., Frisch, A., Hender, J., \& Gilligam, J. J. (2007). Long-distance oceanic movement of a solitary dugong (Dugong dugon) to the Cocos (Keeling) Islands. Aquatic Mammals, 33, 175-178. DOI 110.1578/AM.1533.1572.2007.1175

Hoffman, J. I. \& Amos, W. (2005). Microsatellite genotyping errors: detection approaches, common sources and consequences for paternal exclusion. Molecular Ecology, 14, 599-612.

Hunter, M. E., Broderick, D., Ovenden, J. R., Tucker, K. P., Bonde, R. K., McGuire, P. M., \& Lanyon, J. M. (2010). Characterization of highly informational crossspecies microsatellite panels for the Australian dugong (Dugong dugon) and the Florida manatee (Trichechus manatus latirostris) including five novel primers. Molecular Ecology Resources, 10, 368-377.

Hunter, M. E., Auil-Gomez, N. E., Tucker, K. P., Bonde, R. K., Powell, J., \& McGuire, P. M. (2010). Low genetic variation and evidence of limited dispersal in the regionally important Belize manatee. Animal Conservation, 13, 592-602.

Jayasankar, P., Anoop, B., Rajagopalan, M., Yousuf, K. S. S. M., Reynold, P., Krishnakumar, P. K., Afsal, V. V., \& Anoop, A. K. (2009). Indian Efforts on the Inventorization of Marine Mammal Species for their Conservation and Management. Asian Fisheries Science, 22, 143-155. 
Kalinowski, S. T., Taper, M. L., \& Marshall, T. C. (2007). Revising how the computer program CERVUS accommodates genotyping error increases success in paternity assignment. Molecular Ecology, 16, 1099-1006.

Kellogg, M. E. (2008). Sirenian conservation genetics and Florida manatee (Trichechus manatus latirostris) cytogenetics. PhD dissertation. Florida, USA: University of Florida.

Kocher, T. D., Thomas, W. K., Meyer, A., Edwards, S. V., Pääbo, S., Villablanca, F. X., \& Wilson, A. C. (1989). Dynamics of mitochondrial DNA evolution in animals: amplification and sequencing with conserved primers. Proceedings of the National Academy of Sciences, 8(16), 6196-6200.

Koressaar, T., \& Remm, M. (2007). Enhancements and modifications of primer design program Primer3. Bioinformatics, 23, 1289-1291.

Luikart, G., \& Cornuet J. M., (1998). Empirical evaluation of a test for identifying recently bottlenecked populations from allele frequency data. Conservation Biology, 12(1), 228-237.

Marsh, H. (2008). Dugong dugon. In: IUCN 2012. IUCN Red List of Threatened Species. Version 2012.1. www.iucnredlist.org

Marsh, H., Eros, C., Corkeron, P., \& Breen, B. (1999). A conservation strategy for dugongs: implications of Australian research. Marine and Freshwater Research, 50(8), $979-990$.

Marsh, H., Heinsohn, G. E., \& Marsh, L. M. (1984). Breeding cycle, life history and population dynamics of the dugong, Dugong dugon,(Sirenia: Dugongidae). Australian Journal of Zoology, 32, 767-88.

Marsh, H., O’Shea, T. J., \& Reynolds III, J. E. (2012). Ecology and Conservation of the Sirenia: Dugongs and Manatees. Cambridge, United Kingdom: Cambridge University Press.

Marsh, H., Penrose, H., Eros, C., \& Hugues, J., (2002). Dugong: status report and action plans for countries and territories. I. S. S. S. Group UNEP: Early Warning and Assessment Report Series. UNEP/DEWA/RS.02-1

Maruyama, T., \& Fuerst, P.A. (1985). Population bottlenecks and nonequilibrium models in population genetics. ii. Number of alleles in a small population that was formed by a recent bottleneck. Genetics, 111(3), 675-689. 
McDonald, B. (2005). Population genetics of dugongs around Australia: Implications of gene flow and migration. Ph.D. dissertation. Townsville, Australia: James Cook University.

McEachern, M. B., Van Vuren, D. H., Floyd, C. H., May, B., \& Eadie, J. M. (2011). Bottlenecks and rescue effects in a fluctuating population of golden-mantled ground squirrels (Spermophilus lateralis). Conservation Genetics, 12, 285-296.

Murata, Y., Nikaido, M., Sasaki, T., Cao, Y., Fukumoto, Y., Hasegawa, M., \& Okada, N. (2003). Afrotherian phylogeny as inferred from complete mitochondrial genomes. Molecular Phylogenetics and Evolution, 28, 253-260.

Murray, B. W. (1996). The estimation of genetic distance and population structure from microsatellite allele frequency data. Retrieved from http://helix.biology.mcmaster.ca/brent/brent.html

Nateekanjanalarp, S., \& Sudara, S. (1992). Dugongs and a plan for their management in Thailand. In Chou, L. M., \& Wilkinson, C. R. (Eds.) Proc. $3^{\text {rd } A S E A N-S c i e n c e}$ and Technology Week Conference. Singapore: National University of Singapore.

Nei, M. (1987). Molecular Evolutionary Genetics. New York, New York: Columbia University Press.

Nei, M., \& Tajima, F. (1981). DNA polymorphism detectable by restriction endonucleases. Genetics, 97(1), 145-163.

Palmer, D. (2004). Phylogeography and population genetic structure of the dugongs in Thailand. Masters thesis. San Jose, California: San Jose State University.

Pause, K., Nourisson, C., Clark, A., Kellogg, M. E., Bonde, R. K., \& McGuire, P. M. (2007). Polymorphic microsatellite DNA markers for the Florida manatee (Trichechus manatus latirostris). Molecular Ecology Notes, 7(6), 1073-1076.

Peakall R., \& Smouse P. E. (2006). GENALEX 6: genetic analysis in Excel. Population genetic software for teaching and research. Molecular Ecology Notes, 6, 288295.

Peakall, R., \& Smouse P. E. (2012). GenAlEx 6.5: genetic analysis in Excel. Population genetic software for teaching and research-an update. doi:10.1093/bioinformatics/bts460

Peery, M. Z., Kirby, R., Reid, B. N., Stoelting, R., Doucet-Be“er, E., Robinson, S., VA Squez-Carrillo, C., Pauli, J. N., \& Palsbøll, P. J. (2012). Reliability of genetic bottleneck tests for detecting recent population declines. Molecular Ecology, 21, 
3403-3418.

Pritchard, J. K., Stephens, M., \& Donnelly, P. (2000). Inference of population structure using multilocus genotype data. Genetics, 155, 945-959.

Raymond, M., \& Rousset., F. (1995). GENEPOP (Version 1.2): Population genetics software for exact tests and ecumenisms. Journal of Heredity, 86(3), 248-249.

Rogers, A. R., \& Harpending, H. (1992). Population growth makes waves in the distribution of pairwise genetic differences. Molecular Biology and Evolution, 9(3), 552-569.

Ronquist, F., \& Huelsenbeck, J. P. (2003). MrBayes 3: Bayesian phylogenetic inference under mixed models. Bioinformatics, 19, 1572-1574.

Sheppard, J. K., Marsh, H., Jones, R. E., \& Lawler, I. R. (2010). Dugong habitat use in relation to seagrass nutrients, tides, and diel cycles. Marine Mammal Science, 26, 855-879.

Sheppard, J. K., Preen, A. R., Marsh, H., Lawler, I. R., Whiting, S. D., \& Jones, R. E. (2006). Movement heterogeneity of dugongs, Dugong dugon (Müller), over large spatial scales. Journal of Experimental Marine Biology and Ecology, 334, 64-83.

Slatkin, M. (1995). A measure of population subdivision among populations based on microsatellite allele frequencies. Genetics, 139, 457-462.

Taberlet, P., Griffin, S., Goosens, B., Questiau, S., Manceau, V., Escaravage, N., Waits, L. P., \& Bouvet, J. (1996). Reliable genotyping of samples with very low DNA quantities using PCR. Nucleic Acids Research, 24(16), 3189-3194.

Tajima, F. (1989). Statistical method for testing the neutral mutation hypothesis by DNA polymorphism. Genetics, 123(3), 585-595.

Tamura, K., Peterson, D., Peterson, N., Stecher, G., Nei, M., \& Kumar, S. (2011). MEGA5: Molecular evolutionary genetics analysis using maximum likelihood, evolutionary distance, and maximum parsimony methods. Molecular Biology and Evolution, 28(10), 2731-2739. doi: 10.1093/molbev/msr121

Thompson, J. D., Higgins, D. G., \& Gibson, T. J. (1994). CLUSTAL W: improving the sensitivity of progressive multiple sequence alignment through sequence weighting, position-specific gap penalties and weight matrix choice. Nucleic Acids Research, 22(22), 4673-4680. 
Tikel, D. (1997). Using a genetic approach to optimize dugong (Dugong dugon) conservation management. Ph.D. Thesis. Townsville: Australia James Cook University.

Tringali, M. D., Seyoum, S., Carney, S. L., Davis, M. C., Rodriguez-Lopez, M. A., Reynolds, III, J. E., and Haubold, E. (2008). Eighteen new polymorphic microsatellite markers for the endangered Florida manatee (Trichechus manatus latirostris). Molecular Ecology Resources, 8, 328-331. 